\title{
Effects of Chinese Dietary Pattern of Fat Content, n-6/n-3 Polyunsaturated Fatty Acid Ratio, and Cholesterol Content on Lipid Profile in Rats
}

\author{
Xian-Guo Zou, ${ }^{1}$ Yu-Hua Huang, ${ }^{1}$ Hong-Yan Li ${ }^{D},{ }^{1}$ Tong-Cheng Xu, \\ Ya-Wei Fan, ${ }^{1}$ Jing Li, ${ }^{1}$ and Ze-Yuan Deng $\mathbb{D}^{1,3}$ \\ ${ }^{1}$ State Key Lab of Food Science \& Technology, Nanchang University, Nanchang, Jiangxi 330047, China \\ ${ }^{2}$ Institute of Agro-Food Science \& Technology, Shandong Academy of Agricultural Sciences, Jinan 250100, China \\ ${ }^{3}$ College of Food Science \& Technology, Nanchang University, Nanchang, Jiangxi 330047, China \\ Correspondence should be addressed to Hong-Yan Li; lihongyan@ncu.edu.cn and Ze-Yuan Deng; zeyuandeng@hotmail.com
}

Received 26 October 2017; Revised 29 January 2018; Accepted 8 February 2018; Published 18 March 2018

Academic Editor: Ernesto S. Nakayasu

Copyright (C) 2018 Xian-Guo Zou et al. This is an open access article distributed under the Creative Commons Attribution License, which permits unrestricted use, distribution, and reproduction in any medium, provided the original work is properly cited.

\begin{abstract}
This study aims to investigate the effect of Chinese diet pattern of fat content ( $30 \%$ or $36.06 \%), \mathrm{n}-6 / \mathrm{n}-3$ polyunsaturated fatty acid (PUFA) ratio (5:1 or $9: 1)$, and cholesterol content $(0.04$ or $0.057 \mathrm{~g} / \mathrm{kg}$ total diet) on lipid profile using a rat model. Results showed that rats' body weights (BWs) were controlled by the simultaneous intakes of cholesterol level of $0.04 \mathrm{~g} / \mathrm{kg}$ total diet and $\mathrm{n}-6 / \mathrm{n}-3$ ratio of $5: 1$. In addition, under high-fat diet, increased cholesterol feeding led to increased total cholesterol (TC) and low density lipoprotein cholesterol (LDL-C) levels and decreased triacylglycerols (TG) in rats' plasma. However, high density lipoprotein cholesterol (HDL-C) level and the ratios of HDL-C/LDL-C and HDL-C/TC in rats' plasma increased in response to simultaneous intakes of low n-6/n-3 ratio $(5: 1)$ and cholesterol $(0.04 \mathrm{~g} / \mathrm{kg}$ total diet $)$ even under high-fat diet. Moreover, as the n-6/n-3 PUFA ratio in the diet decreased, the proportion of n-3 PUFAs increased in plasma, liver, and muscle and resulted in the decrease of n-6/n-3 PUFA ratio.
\end{abstract}

\section{Introduction}

The amount and type of dietary fats largely influence plasma lipid content and play an important role in diseases prevention and development $[1,2]$. In recent decade years, the number of obese and/or overweight people in China was up to 2,600 million and the data are increasing, which was largely associated with the unhealthy diet of high fat and cholesterol [3]. Data from National Nutrition and Health Survey in China showed that the average intake of fat was $76.2 \mathrm{~g} / 60 \mathrm{~kg}$.body weight (BW).d in the whole country (30\% total calories) and $85.6 \mathrm{~g} / 60 \mathrm{~kg} \cdot \mathrm{BW} \cdot \mathrm{d}$ in the urban areas $(36.06 \%$ total calories) [4]. And the consumption ratio of $n-6 / n-3$ was $9: 1$ in both the whole country and the urban areas [5]. Moreover, the average cholesterol consumption in the whole country and the urban areas was 0.04 and $0.057 \mathrm{~g} / \mathrm{kg}$ total diet, respectively $[4,5]$. It is obvious that the Chinese dietary pattern of fat and cholesterol has surpassed the recommended level and the ratio of $n-6 / n-3$ almost reached the upper level of FAO/WHO standards [6]. Besides, it was found that the increased Chinese dietary pattern of fat and cholesterol was positively associated with the increased morbidity and mortality of cardiovascular disease, with $R^{2}$ value of 0.98 and 1.00 , respectively [5]. However, to the best of our knowledge, little has been reported regarding the influence of Chinese dietary pattern of fat and cholesterol on lipid metabolism.

Currently, there are many studies, using rat models, investigating the effects of different fatty acid ratios with or without cholesterol treatment on rats' lipid metabolism. For example, Parrish et al. [7] found that there were attenuated perirenal and epididymal fat accumulation and reduction in adipocyte size in rats fed with a high-fat diet consisting of fish oil, compared to those fed with lard. Wong et al. [8] and Balasubramaniam et al. [9] reported that, in rats, dietary long-chain n-3 polyunsaturated fatty acid (PUFA) could reduce both triacylglycerols (TG) and cholesterol plasma 
TABLE 1: The grouping of rats according to the diet of Chinese people.

\begin{tabular}{|c|c|c|c|c|}
\hline & $\begin{array}{c}{ }^{\mathrm{b}} \text { The energy proportion } \\
\text { of fat }(\%)\end{array}$ & $\begin{array}{l}{ }^{c} \text { The dose for oral administration of the } \\
\text { blended oil in rats }(\mathrm{mL} / 100 \mathrm{~g} \cdot \mathrm{BW} \cdot \mathrm{d})\end{array}$ & $\begin{array}{l}{ }^{\mathrm{d}} \text { The cholesterol level } \\
\text { (g/kg total diet) }\end{array}$ & $n-6 / n-3$ \\
\hline${ }^{\mathrm{a}} \mathrm{EG} 1$ & 36.06 & 0.8 & 0.04 & $9: 1$ \\
\hline EG 2 & 36.06 & 0.8 & 0.057 & $9: 1$ \\
\hline EG 3 & 36.06 & 0.8 & 0.04 & $5: 1$ \\
\hline EG 4 & 36.06 & 0.8 & 0.057 & $5: 1$ \\
\hline CG 1 & 30 & 0.6 & 0.04 & $9: 1$ \\
\hline CG 2 & 30 & 0.6 & 0.057 & $9: 1$ \\
\hline
\end{tabular}

${ }^{\mathrm{a}} \mathrm{EG}$ was experimental group and CG was control group. ${ }^{\mathrm{b}}$ The energy of fat consumed in the urban areas (36.06\%) and in the whole country (30\%), respectively. ${ }^{c}$ Average intake of blended oils in rats converted from Chinese dietary consumption per day in the urban areas $(40 \mathrm{~g} / 60 \mathrm{~kg} \cdot \mathrm{BW} \cdot \mathrm{d})$ and in the whole country $(30 \mathrm{~g} / 60 \mathrm{~kg} \cdot \mathrm{BW} \cdot \mathrm{d})$, respectively. ${ }^{\mathrm{d}}$ The cholesterol proportion of total diet in the whole country $(0.04 \mathrm{~g} / \mathrm{kg}$ total diet) and the urban areas $(0.057 \mathrm{~g} / \mathrm{kg}$ total diet), respectively.

concentrations. Yang et al. [10] found that comparing with rat group fed with $n-6 / n-3$ ratio of $20: 1$, rat groups with the ratios of $1: 1$ and $5: 1$ had significantly decreased serum levels of total cholesterol (TC), low density lipoprotein cholesterol (LDL-C), and proinflammatory cytokines. Besides, Huang et al. [11] reported that the cholesterol-added diet (1\%) did not impair the response to long-chain n-3 PUFA but increased the plasma cholesterol content and the liver weight. Moreover, $\mathrm{Lu}$ and $\mathrm{Wu}$ [12] found that added $1 \%$ cholesterol to diets led to a reduction of plasma TG and high density lipoprotein (HDL) levels and an increase of liver TG and cholesterol levels.

Therefore, the aim of this study was to investigate the influence of different fat intake, $n-6 / n-3$ ratio, and cholesterol on lipids metabolism using a rat model according to the Chinese diet pattern. BWs, plasma lipid levels, and fatty acid compositions in rats' plasma and tissues were determined and analyzed.

\section{Methods and Materials}

2.1. Materials and Chemicals. A total of 72 young male Sprague-Dawley rats (two or three months, $270 \pm 33 \mathrm{~g}$ at the beginning of the experiment) were purchased from Experimental Animal Center of Jiangxi Medical College, China (approval number: 02196-02). They were randomly divided into 6 groups with 12 rats per group (Table 1) according to the different consumption of fat energy (30 or $36.06 \%)$, n$6 / \mathrm{n}-3$ ratio $(5: 1$ or $9: 1)$, and cholesterol $(0.04$ or $0.057 \mathrm{~g} / \mathrm{kg}$ total diet) and then were housed in the individual cages at a constant temperature of $22 \pm 1^{\circ} \mathrm{C}$ with a normal $12: 12$ hours of light dark cycles. The six groups were Experimental Groups 1, 2, 3, and 4 (EG 1, 2, 3, and 4) and Control Groups 1 and 2 (CG 1 and 2). Except for different contents of palm oil and cholesterol in different groups, the compositions of other nutrients in the diet given to rats were identical (Table 2). Besides, rats in each group was intragastric gavage administered with blended oil of $0.8 \mathrm{~mL} / 100 \mathrm{~g} \cdot \mathrm{BW} \cdot \mathrm{d}(\mathrm{EG} \mathrm{1,2}$, 3 , and 4 ) or $0.6 \mathrm{~mL} / 100 \mathrm{~g} \cdot \mathrm{BW} \cdot \mathrm{d}$ (CG 1 and 2), so as to maintain the dietary consumption of fat energy and $n-6 / n-3$ ratio in different group. The physical blended oil administered in each group consists of different proportions of camellia oil, sunflower oil, and linseed oil (fatty acid compositions shown in Table 3), and their formula in each group was shown in
Table 4. All procedures involving animals were approved by the Ethics Committee, Nanchang University, and conducted in accordance with the guidelines of China for the care and use of laboratory animals.

2.2. Animal Treatment and Sampling. Before treatment, blood samples (about $0.5-1.0 \mathrm{~mL}$ ) were collected from rats' tail vein to measure the biochemical indices, such as TC, TG, LDL-C, and HDL-C. TC and TG were measured enzymatically on the automatic biochemistry analyzer (Beckman, CX4) because of their methodology, calibrators, and controls [13]. The very low density lipoprotein cholesterol (VLDL-C) and LDL-C were precipitated using dextran sulfate and magnesium sulfate before HDL-C was measured enzymatically on the same instrument. LDL-C was calculated from these values (TC, HDL-C, and TG) using the formula of Friedewald et al. [14] when the TG level was $<4.52 \mathrm{mmol} / \mathrm{L}$.

After 7-day basal chow, there was no difference in BWs or serum lipid profile among the six groups. Then, each group was maintained on the experimental diet for 60 days. Rats had free access to water. BWs were monitored weekly. After 60 days' treatment, rats were fasted overnight (about $12 \mathrm{~h}$, with water ad libitum) to reduce the feeding impact and then sacrificed under diethyl ether anesthesia. Blood samples were collected by cardiac puncture into clean test tubes containing $1 \%$ heparin sodium solution $(\mathrm{w} / \mathrm{w})$, centrifuged $\left(4^{\circ} \mathrm{C}, 2500 \mathrm{r} / \mathrm{min}\right.$ for $\left.15 \mathrm{~min}\right)$ to get the plasma fraction, and then promptly stored at $-80^{\circ} \mathrm{C}$ until analysis. The main organs and tissues (brain, heart, liver, and muscle) were removed and immediately rinsed in phosphate-buffered saline twice and then stored at $-80^{\circ} \mathrm{C}$ until analysis.

2.3. Measurement of Biochemical Indices. Plasma lipid levels of TG, TC, LDL-C, and HDL-C after treatment were determined by automatic biochemistry analyzer (CX4, Beckman) as described above.

2.4. Fatty Acid Composition Analysis in Blood and Tissues. Total lipids were extracted with chloroform/methanol (v/v, 1:1) from the liver, brain, heart, muscle, and plasma according to the method of Folch et al. [15]. The obtained lipids were converted to fatty acid methyl esters (FAMEs) following the method of Lei et al. [16] and then analyzed by gas 
TABLE 2: The components and nutrition compositions of basal chow and the amount of palm oil and cholesterol of each group.

\begin{tabular}{|c|c|c|c|c|c|c|}
\hline \multirow{2}{*}{ Basal components $(\mathrm{g} / \mathrm{kg})$} & \multicolumn{6}{|c|}{ Groups } \\
\hline & EG1 & EG2 & EG3 & EG4 & CG1 & CG2 \\
\hline Corn flour & 480 & 480 & 480 & 480 & 480 & 480 \\
\hline Soybean flour & 210 & 210 & 210 & 210 & 210 & 210 \\
\hline Wheat bran & 170 & 170 & 170 & 170 & 170 & 170 \\
\hline Wheat flour & 50 & 50 & 50 & 50 & 50 & 50 \\
\hline Fish meal & 50 & 50 & 50 & 50 & 50 & 50 \\
\hline $\mathrm{CaH}_{2} \mathrm{PO}_{4}$ & 15 & 15 & 15 & 15 & 15 & 15 \\
\hline Limestone power & 15 & 15 & 15 & 15 & 15 & 15 \\
\hline Salt & 5 & 5 & 5 & 5 & 5 & 5 \\
\hline Bean oil & 6 & 6 & 6 & 6 & 6 & 6 \\
\hline \multicolumn{7}{|l|}{ Nutrient compositions (\%) } \\
\hline Carbohydrate & \multicolumn{6}{|c|}{52.58} \\
\hline Fat & \multicolumn{6}{|c|}{3.50} \\
\hline Protein & \multicolumn{6}{|c|}{21.2} \\
\hline Moisture & \multicolumn{6}{|c|}{8.80} \\
\hline Ash & \multicolumn{6}{|c|}{6.78} \\
\hline Fiber & \multicolumn{6}{|c|}{2.80} \\
\hline \multicolumn{7}{|l|}{ Additional components } \\
\hline Palm oil & 90 & 90 & 86 & 86 & 61 & 61 \\
\hline Cholesterol (mg/kg) & 40 & 57 & 40 & 57 & 40 & 57 \\
\hline $\begin{array}{l}\text { EG was experimental group at } \\
\text { total diet, and } \mathrm{n}-6 / \mathrm{n}-39: 1) \text {; } \\
\text { oil, cholesterol of } 0.04 \mathrm{~g} / \mathrm{kg} \text { to } \\
(0.6 \mathrm{~mL} \text { blended oil, } 6.1 \% \text { paln } \\
\text { diet, and } \mathrm{n}-6 / \mathrm{n}-3 \mathrm{9}: 1) \text {. Differe } \\
\text { (camellia oil } 18.6 \mathrm{~g} \text {, sunflower }\end{array}$ & $\begin{array}{l}\text { rol gre } \\
\text { ded o } \\
6 / n-3 \\
\text { of } 0 . \\
\text { of bler }\end{array}$ & $\begin{array}{l}\text { dietary } \\
1 \text {, chole } \\
3 \mathrm{~mL} \text { bl } \\
\text { iet, and } \\
\text { g) for }\end{array}$ & $\begin{array}{l}\text { group } \\
\mathrm{g} / \mathrm{kg} \text { to } \\
\% \text { palm } \\
\text { CG2 ( } \\
\text { G2 (can }\end{array}$ & $\begin{array}{l}\text { blende } \\
-6 / n-3 \\
\text { ol of } 0 .( \\
\text { d oil, } 6 . \\
\text { sunflon }\end{array}$ & $\begin{array}{l}\text { oil, ch } \\
3 \mathrm{~mL} \text { bl } \\
\text { diet, an } \\
\text { holester } \\
\text { d linsee }\end{array}$ & $\begin{array}{l}04 \mathrm{~g} / \mathrm{kg} \\
\% \text { palm } \\
1) ; \mathrm{CG} 1 \\
\mathrm{~kg} \text { total } \\
\text { 33/EG4 }\end{array}$ \\
\hline
\end{tabular}

chromatography (model 6890N, Agilent Technologies, USA) equipped with an autoinjector, a fused-silica capillary column (CP-Sil 88, $100 \mathrm{~m} \times 0.25 \mathrm{~mm} \times 0.2 \mu \mathrm{m}$ i.d.), and a flame ionization detector (FID) and operated on in splitless mode. The injector and detector temperatures were maintained at 250 and $260^{\circ} \mathrm{C}$, respectively. The column temperature was held at $45^{\circ} \mathrm{C}$ for $3 \mathrm{~min}$ and then programmed to $175^{\circ} \mathrm{C}$ for $27 \mathrm{~min}$ at the rate of $13^{\circ} \mathrm{C} / \mathrm{min}$. The temperature was then further increased to $215^{\circ} \mathrm{C}$ at the rate of $4^{\circ} \mathrm{C} / \mathrm{min}$ and held for $35 \mathrm{~min}$. The oven temperature program was sustained for $86 \mathrm{~min}$ in total. The carrier gas was nitrogen, and the total gas flow rate was $52 \mathrm{~mL} / \mathrm{min}$. The injecting sample volume was $1 \mu \mathrm{L}$. Analysis of all peaks was accomplished by comparison of their retention times with FAME standards.

2.5. Statistical Analysis. Data were presented as mean \pm SD and carried out using the Kruskal-Wallis one-way analysis by Statistical Package for the Social Sciences (SPSS) to compare differences between groups. $P$ values less than $0.05(P<0.05)$ were considered significant.

\section{Results}

3.1. BWs. Under different diet of fat, n-6/n-3 ratio, and cholesterol, the change of BWs among six groups showed difference from the fourth week (Table 5). Compared with CG2 fed with fat energy of 30\%, average BW in EG2 fed with higher fat energy of $36.06 \%$ was significantly increased $(P<0.05)$. Besides, with the same fat energy of $36.06 \%$ and n-6/n-3 ratio of $9: 1$, but different cholesterol level of 0.04 or $0.057 \mathrm{~g} / \mathrm{kg}$ total diet, there was no significant difference $(P>0.05)$ of BWs in EG1 and EG2. Also, with the same fat energy of $30 \%$ and $n-6 / n-3$ of $9: 1$, but different cholesterol level of 0.04 or $0.057 \mathrm{~g} / \mathrm{kg}$ total diet, there was no significant difference $(P>0.05)$ of BWs in CG1 and CG2. However, with the same fat energy of $36.06 \%$ and $n-6 / n-3$ of $5: 1$, the average BW in EG3 feeding cholesterol of $0.04 \mathrm{~g} / \mathrm{kg}$ total diet was significantly lower than that in EG4 feeding cholesterol of $0.057 \mathrm{~g} / \mathrm{kg}$ total diet $(P<0.05)$. Rats in EG4 fed with low $\mathrm{n}-6 / \mathrm{n}-3$ ratio $(5: 1)$ but high cholesterol $(0.057 \mathrm{~g} / \mathrm{kg}$ total diet $)$ showed no significant difference in BWs compared to those in EG1 feeding high $n-6 / n-3$ ratio $(9: 1)$ but low cholesterol $(0.04 \mathrm{~g} / \mathrm{kg}$ total diet $)$. Interestingly, rats in EG3 taking low $\mathrm{n}$ $6 / \mathrm{n}-3$ ratio $(5: 1)$ and cholesterol $(0.04 \mathrm{~g} / \mathrm{kg}$ total diet) showed significantly decreased BWs compared to those in EG2 taking high $\mathrm{n}-6 / \mathrm{n}-3$ ratio $(9: 1)$ and cholesterol $(0.057 \mathrm{~g} / \mathrm{kg}$ total diet). All these results suggested that rats' BW increased as the increase of fat energy, whereas the increase slowed down by reducing the intake of cholesterol under low intake of n$6 / n-3$ ratio.

3.2. The Plasma Lipid Levels. As shown in Table 6, for the groups with the same contents of fat energy (36.06\%) and n6/n-3 (9:1), rats in EG2 fed with cholesterol level of $0.057 \mathrm{~g} / \mathrm{kg}$ 
TABLE 3: Main fatty acid compositions (\% area) of four oils used.

\begin{tabular}{|c|c|c|c|c|}
\hline Fatty acids & Palm oil & Camellia oil & Sunflower oil & Linseed oil \\
\hline 14:0 & 1.19 & 0.04 & 0.06 & 0.05 \\
\hline $16: 0$ & 60.28 & 8.79 & 6.34 & 5.19 \\
\hline $9 c 16: 1$ & 0.11 & 0.09 & 0.06 & 0.06 \\
\hline 18:0 & 5.66 & 2.29 & 5.67 & 3.52 \\
\hline $9 t 18: 1$ & 0.18 & 2.33 & 1.71 & 1.55 \\
\hline $9 \mathrm{c} 18: 1 \mathrm{OA}$ & 23.98 & 76.46 & 19.12 & 20.35 \\
\hline 11c18:1 & 1.41 & ND & 1.41 & 1.35 \\
\hline 9c12c18:2n-6 LA & 5.51 & 6.88 & 58.66 & 14.31 \\
\hline $20: 0$ & 0.36 & 0.05 & 0.30 & 0.23 \\
\hline $18: 3 n-6$ & ND & ND & ND & 0.83 \\
\hline $5 c 20: 1$ & ND & 0.02 & ND & 0.17 \\
\hline 11c20:1 & 0.07 & 0.37 & 0.11 & 5.73 \\
\hline 18:3n-3 ALA & 0.21 & 0.28 & 0.21 & 34.65 \\
\hline $21: 0$ & ND & 0.02 & 0.19 & ND \\
\hline $22: 0$ & 0.05 & 0.01 & 0.56 & 0.07 \\
\hline $22: \ln -9$ & ND & 0.03 & ND & 0.31 \\
\hline 23:0 & 0.03 & 0.01 & ND & ND \\
\hline $24: 0$ & 0.06 & 0.03 & 0.11 & ND \\
\hline TSFA & 67.73 & 11.31 & 13.23 & 9.06 \\
\hline TMUFA & 25.57 & 76.95 & 20.74 & 27.66 \\
\hline TPUFA & 5.73 & 7.26 & 58.87 & 50.28 \\
\hline$n-6 / n-3$ & 26.29 & 24.64 & 279.33 & 0.44 \\
\hline
\end{tabular}

OA, oleic acid; LA, linoleic acid; ALA, alpha-linolenic acid; TSFAs, total saturated fatty acids, the sum of (C14:0 + C16:0 + C18:0 + C20:0 + C21:0 + C22:0 + C23:0 + C24:0 + - - ) TMUFAs, total monounsaturated fatty acids, the sum of $(\mathrm{C} 16: 1+\mathrm{C} 18: 1+\mathrm{C} 20: 1+\mathrm{C} 22: 1+\cdots)$; TPUFAs, total polyunsaturated fatty

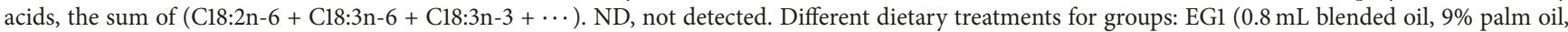
cholesterol of $0.04 \mathrm{~g} / \mathrm{kg}$ total diet, and n-6/n-3 9:1); EG2 (0.8 mL blended oil, $9 \%$ palm oil, cholesterol of $0.057 \mathrm{~g} / \mathrm{kg}$ total diet, and n-6/n-3 9:1); EG3 (0.8 mL blended oil, 8.6\% palm oil, cholesterol of $0.04 \mathrm{~g} / \mathrm{kg}$ total diet, and n-6/n-3 $5: 1)$; EG4 ( $0.8 \mathrm{~mL}$ blended oil, $8.6 \%$ palm oil, cholesterol of $0.057 \mathrm{~g} / \mathrm{kg}$ total diet, and $\mathrm{n}-6 / \mathrm{n}-35: 1)$; CG1 ( $0.6 \mathrm{~mL}$ blended oil, $6.1 \%$ palm oil, cholesterol of $0.04 \mathrm{~g} / \mathrm{kg}$ total diet, and n-6/n-3 9:1); CG2 (0.6 mL blended oil, $6.1 \%$ palm oil, cholesterol of $0.057 \mathrm{~g} / \mathrm{kg}$ total diet, and $\mathrm{n}-6 / \mathrm{n}-39: 1$ ). Different proportions of blended oil (g/100 g) for groups: EG1/EG2 (camellia oil $10 \mathrm{~g}$, sunflower oil $74 \mathrm{~g}$, and linseed oil 16 g); EG3/EG4 (camellia oil 18.6 g, sunflower oil $53.5 \mathrm{~g}$, and linseed oil 27.9 g); CG1/CG2 (camellia oil $10.2 \mathrm{~g}$, sunflower oil $73.5 \mathrm{~g}$, and linseed oil $16.3 \mathrm{~g}$ ).

TABLE 4: The formulation design of blended oil intragastric gavage administered in each group.

\begin{tabular}{lccc}
\hline Oil $(\mathrm{g} / 100 \mathrm{~g})$ & EG1/EG2 & EG3/EG4 & CG1/CG2 \\
\hline Camellia oil & 10 & 18.6 & 10.2 \\
Sunflower oil & 74 & 53.5 & 73.5 \\
Linseed oil & 16 & 27.9 & 16.3 \\
Total & 100 & 100 & 100 \\
& Final fatty acid ratios administered to rats considering the oils in the chow & $1: 1.21: 1.03$ \\
$\mathrm{~S}: \mathrm{M}: \mathrm{P}$ & $1: 1.22: 1$ & $1: 1.19: 1$ & 9.07 \\
$\mathrm{n}-6 / \mathrm{n}-3$ & 9.12 & 5.04 & \\
\hline
\end{tabular}

EG was experimental group and CG was control group. S: total saturated fatty acids; M: total monounsaturated fatty acids; TPUFA: total polyunsaturated fatty acids. Different dietary treatments for groups: EG1 ( $0.8 \mathrm{~mL}$ blended oil, $9 \%$ palm oil, cholesterol of $0.04 \mathrm{~g} / \mathrm{kg}$ total diet, and n-6/n-3 9:1); EG2 (0.8 mL blended oil, $9 \%$ palm oil, cholesterol of $0.057 \mathrm{~g} / \mathrm{kg}$ total diet, and n-6/n-3 9:1); EG3 ( $0.8 \mathrm{~mL}$ blended oil, $8.6 \%$ palm oil, cholesterol of $0.04 \mathrm{~g} / \mathrm{kg}$ total diet, and n-6/n$35: 1)$; EG4 (0.8 mL blended oil, $8.6 \%$ palm oil, cholesterol of $0.057 \mathrm{~g} / \mathrm{kg}$ total diet, and $\mathrm{n}-6 / \mathrm{n}-35: 1)$; CG1 (0.6 mL blended oil, $6.1 \%$ palm oil, cholesterol of $0.04 \mathrm{~g} / \mathrm{kg}$ total diet, and n-6/n-3 9:1); CG2 (0.6 mL blended oil, $6.1 \%$ palm oil, cholesterol of $0.057 \mathrm{~g} / \mathrm{kg}$ total diet, and n-6/n-3 9:1). Different proportions of blended oil (g/100 g) for groups: EG1/EG2 (camellia oil $10 \mathrm{~g}$, sunflower oil $74 \mathrm{~g}$, and linseed oil $16 \mathrm{~g}$ ); EG3/EG4 (camellia oil $18.6 \mathrm{~g}$, sunflower oil $53.5 \mathrm{~g}$, and linseed oil 27.9 g); CG1/CG2 (camellia oil $10.2 \mathrm{~g}$, sunflower oil $73.5 \mathrm{~g}$, and linseed oil $16.3 \mathrm{~g}$ ).

total diet showed significantly $(P<0.05)$ higher levels of TC $(1.73 \mathrm{mmol} / \mathrm{L})$ in plasma than those in EG1 fed with cholesterol level of $0.04 \mathrm{~g} / \mathrm{kg}$ total diet $(1.28 \mathrm{mmol} / \mathrm{L})$. Likewise, with the same contents of fat energy (36.06\%) and n-6/n-3 (5:1), the TC content in EG4 (cholesterol of $0.057 \mathrm{~g} / \mathrm{kg}$ total diet) was $2.06 \pm 0.24 \mathrm{mmol} / \mathrm{L}$, which was significantly higher $(P<0.05)$ than that in EG3 (cholesterol of $0.04 \mathrm{~g} / \mathrm{kg}$ total diet), $1.28 \pm 0.21 \mathrm{mmol} / \mathrm{L}$. Besides, significant difference $(P<$ 0.05) was found between CG2 (cholesterol of $0.057 \mathrm{~g} / \mathrm{kg}$ total diet) and CG1 (cholesterol of $0.04 \mathrm{~g} / \mathrm{kg}$ total diet), containing 
TABLE 5: The body weights (g) of rats in weeks.

\begin{tabular}{|c|c|c|c|c|c|c|}
\hline The week & EG1 & EG2 & EG3 & EG4 & CG1 & CG2 \\
\hline 0th & $277 \pm 26$ & $277 \pm 31$ & $277 \pm 40$ & $277 \pm 40$ & $278 \pm 32$ & $277 \pm 32$ \\
\hline 1st & $307 \pm 20$ & $313 \pm 25$ & $313 \pm 27$ & $318 \pm 32$ & $316 \pm 32$ & $306 \pm 19$ \\
\hline 2nd & $349 \pm 28$ & $351 \pm 23$ & $349 \pm 28$ & $348 \pm 32$ & $343 \pm 35$ & $330 \pm 19$ \\
\hline $3 \mathrm{rd}$ & $385 \pm 34$ & $386 \pm 21$ & $361 \pm 32$ & $373 \pm 38$ & $370 \pm 38$ & $362 \pm 22$ \\
\hline 4 th & $412 \pm 30^{c}$ & $410 \pm 22^{c}$ & $368 \pm 31^{\mathrm{a}}$ & $401 \pm 30^{b c}$ & $390 \pm 29^{\mathrm{ac}}$ & $380 \pm 27^{\mathrm{ab}}$ \\
\hline 5 th & $426 \pm 32^{c}$ & $429 \pm 22^{c}$ & $374 \pm 29^{\mathrm{a}}$ & $423 \pm 33^{c}$ & $413 \pm 30^{b c}$ & $391 \pm 25^{\mathrm{ab}}$ \\
\hline 6 th & $447 \pm 27^{\mathrm{c}}$ & $435 \pm 21^{c}$ & $378 \pm 25^{\mathrm{a}}$ & $444 \pm 26^{c}$ & $424 \pm 29^{b c}$ & $393 \pm 30^{\mathrm{ab}}$ \\
\hline 7 th & $458 \pm 32^{c}$ & $450 \pm 25^{c}$ & $378 \pm 26^{\mathrm{a}}$ & $456 \pm 31^{c}$ & $439 \pm 31^{b c}$ & $412 \pm 29^{\mathrm{ab}}$ \\
\hline 8th & $466 \pm 30^{c}$ & $463 \pm 26^{c}$ & $375 \pm 28^{\mathrm{a}}$ & $460 \pm 31^{c}$ & $452 \pm 29^{b c}$ & $423 \pm 27^{b}$ \\
\hline 9th & $481 \pm 25^{\mathrm{c}}$ & $474 \pm 28^{c}$ & $376 \pm 26^{\mathrm{a}}$ & $465 \pm 28^{c}$ & $462 \pm 30^{b c}$ & $431 \pm 29^{b c}$ \\
\hline
\end{tabular}

Values presented as means $(n=12) \pm$ SD. Mean values within each row followed by different letters $(\mathrm{a}, \mathrm{b}, \mathrm{c})$ are significantly $(P<0.05)$ different. Different dietary treatments for groups: EG1 ( $0.8 \mathrm{~mL}$ blended oil, $9 \%$ palm oil, cholesterol of $0.04 \mathrm{~g} / \mathrm{kg}$ total diet, and $\mathrm{n}-6 / \mathrm{n}-3$ 9:1); EG2 (0.8 mL blended oil, $9 \%$ palm oil, cholesterol of $0.057 \mathrm{~g} / \mathrm{kg}$ total diet, and n-6/n-3 9:1); EG3 ( $0.8 \mathrm{~mL}$ blended oil, 8.6\% palm oil, cholesterol of $0.04 \mathrm{~g} / \mathrm{kg}$ total diet, and n-6/n-3 $5: 1)$; EG4 (0.8 mL blended oil, $8.6 \%$ palm oil, cholesterol of $0.057 \mathrm{~g} / \mathrm{kg}$ total diet, and $\mathrm{n}-6 / \mathrm{n}-35: 1)$; CG1 ( $0.6 \mathrm{~mL}$ blended oil, $6.1 \%$ palm oil, cholesterol of $0.04 \mathrm{~g} / \mathrm{kg}$ total diet, and n-6/n-3 9:1); CG2 (0.6 mL blended oil, 6.1\% palm oil, cholesterol of $0.057 \mathrm{~g} / \mathrm{kg}$ total diet, and n-6/n-3 9:1). Different proportions of blended oil (g/100 g) for groups: EG1/EG2 (camellia oil $10 \mathrm{~g}$, sunflower oil $74 \mathrm{~g}$, and linseed oil 16 g); EG3/EG4 (camellia oil 18.6 g, sunflower oil 53.5 g, and linseed oil 27.9 g); CG1/CG2 (camellia oil $10.2 \mathrm{~g}$, sunflower oil $73.5 \mathrm{~g}$, and linseed oil $16.3 \mathrm{~g}$ ).

TABLE 6: The biochemical indices of TC, TG, HDL-C, and LDL-C (mmol/L) and the ratios of HDL-C/LDL-C and HDL-C/TC.

\begin{tabular}{|c|c|c|c|c|c|c|c|}
\hline & & EG 1 & EG 2 & EG 3 & EG 4 & CG 1 & CG 2 \\
\hline \multirow{2}{*}{$\mathrm{TC}$} & B & $1.16 \pm 0.11$ & $1.10 \pm 0.13^{(\mathrm{a})}$ & $1.16 \pm 0.20$ & $1.16 \pm 0.15^{(\mathrm{a})}$ & $1.12 \pm 0.09$ & $1.12 \pm 0.12^{(\mathrm{a})}$ \\
\hline & $\mathrm{A}$ & $1.28 \pm 0.30^{\mathrm{a}}$ & $1.73 \pm 0.33^{\mathrm{b}(\mathrm{b})}$ & $1.28 \pm 0.21^{\mathrm{a}}$ & $2.06 \pm 0.24^{\mathrm{c}(\mathrm{b})}$ & $1.23 \pm 0.21^{\mathrm{a}}$ & $1.58 \pm 0.30^{\mathrm{b}(\mathrm{b})}$ \\
\hline \multirow{2}{*}{ TG } & B & $0.48 \pm 0.09$ & $0.41 \pm 0.01^{(\mathrm{b})}$ & $0.44 \pm 0.03$ & $0.53 \pm 0.03^{(\mathrm{b})}$ & $0.51 \pm 0.04$ & $0.48 \pm 0.08$ \\
\hline & $\mathrm{A}$ & $0.43 \pm 0.06^{\mathrm{bc}}$ & $0.35 \pm 0.05^{\mathrm{a}(\mathrm{a})}$ & $0.46 \pm 0.08^{c}$ & $0.38 \pm 0.04^{\mathrm{ab}(\mathrm{a})}$ & $0.45 \pm 0.12^{\mathrm{bc}}$ & $0.44 \pm 0.08^{\mathrm{bc}}$ \\
\hline \multirow{2}{*}{ HDL-C } & B & $0.70 \pm 0.07$ & $0.69 \pm 0.07$ & $0.73 \pm 0.07^{(\mathrm{b})}$ & $0.78 \pm 1.04^{(\mathrm{a})}$ & $0.70 \pm 0.06^{(\mathrm{b})}$ & $0.67 \pm 0.10^{(\mathrm{b})}$ \\
\hline & A & $0.61 \pm 0.09^{\mathrm{b}}$ & $0.61 \pm 0.12^{b}$ & $0.63 \pm 0.10^{\mathrm{b}(\mathrm{a})}$ & $0.99 \pm 0.11^{\mathrm{c}(\mathrm{b})}$ & $0.54 \pm 0.08^{\mathrm{ab}(\mathrm{a})}$ & $0.50 \pm 0.04^{\mathrm{a}(\mathrm{a})}$ \\
\hline \multirow{2}{*}{ LDL-C } & B & $0.30 \pm 0.04^{(\mathrm{a})}$ & $0.25 \pm 0.07^{(\mathrm{a})}$ & $0.28 \pm 0.07^{(\mathrm{a})}$ & $0.30 \pm 0.09^{(a)}$ & $0.30 \pm 0.07$ & $0.28 \pm 0.09$ \\
\hline & $\mathrm{A}$ & $0.39 \pm 0.07^{\mathrm{a}(\mathrm{b})}$ & $0.42 \pm 0.07^{\mathrm{a}(\mathrm{b})}$ & $0.38 \pm 0.06^{\mathrm{a}(\mathrm{b})}$ & $0.67 \pm 0.11^{\mathrm{b}(\mathrm{b})}$ & $0.36 \pm 0.05^{\mathrm{a}}$ & $0.39 \pm 0.08^{\mathrm{a}}$ \\
\hline \multirow{2}{*}{ HDL-C/LDL-C } & $\mathrm{B}$ & $2.34 \pm 0.23^{(\mathrm{b})}$ & $3.12 \pm 0.24^{(\mathrm{b})}$ & $2.00 \pm 0.53^{(\mathrm{b})}$ & $2.73 \pm 0.65^{(\mathrm{b})}$ & $2.04 \pm 0.48$ & $2.69 \pm 0.32^{(b)}$ \\
\hline & A & $1.52 \pm 0.26^{\mathrm{a}(\mathrm{a})}$ & $1.47 \pm 0.29^{\mathrm{a}(\mathrm{a})}$ & $2.24 \pm 0.26^{\mathrm{b}(\mathrm{a})}$ & $1.53 \pm 0.26^{\mathrm{a}(\mathrm{a})}$ & $2.11 \pm 0.49^{b}$ & $1.97 \pm 0.46^{\mathrm{b}(\mathrm{a})}$ \\
\hline \multirow{2}{*}{ HDL-C/TC } & $\mathrm{B}$ & $0.61 \pm 0.03^{(\mathrm{b})}$ & $0.65 \pm 0.05^{(\mathrm{b})}$ & $0.65 \pm 0.08^{(\mathrm{b})}$ & $0.68 \pm 0.08^{(\mathrm{b})}$ & $0.67 \pm 0.04^{(\mathrm{b})}$ & $0.67 \pm 0.02^{(\mathrm{b})}$ \\
\hline & A & $0.48 \pm 0.08^{\mathrm{b}(\mathrm{a})}$ & $0.36 \pm 0.04^{\mathrm{a}(\mathrm{a})}$ & $0.46 \pm 0.07^{\mathrm{b}(\mathrm{a})}$ & $0.45 \pm 0.08^{\mathrm{b}(\mathrm{a})}$ & $0.40 \pm 0.11^{\mathrm{ab}(\mathrm{a})}$ & $0.37 \pm 0.09^{\mathrm{a}(\mathrm{a})}$ \\
\hline
\end{tabular}

Values presented as means $(n=12) \pm$ SD. B and A represented before and after treatment, respectively. TC, total cholesterol; TG, triacylglycerols; VLDL-C, very low density lipoprotein cholesterol; HDL-C, high density lipoprotein cholesterol; LDL-C, low density lipoprotein cholesterol. Mean values within each row followed by different letters $(\mathrm{a}, \mathrm{b}, \mathrm{c})$ are significantly $(P<0.05)$ different. ${ }^{(\mathrm{a})}$ versus B and ${ }^{(\mathrm{b})}$ versus A. Different dietary treatments for groups: EG1 $(0.8 \mathrm{~mL}$ blended oil, $9 \%$ palm oil, cholesterol of $0.04 \mathrm{~g} / \mathrm{kg}$ total diet, and n-6/n-3 9:1); EG2 (0.8 mL blended oil, $9 \%$ palm oil, cholesterol of $0.057 \mathrm{~g} / \mathrm{kg}$ total diet, and $\mathrm{n}-6 / \mathrm{n}-39: 1)$; EG3 ( $0.8 \mathrm{~mL}$ blended oil, $8.6 \%$ palm oil, cholesterol of $0.04 \mathrm{~g} / \mathrm{kg}$ total diet, and n-6/n-3 5:1); EG4 (0.8 mL blended oil, $8.6 \%$ palm oil, cholesterol of $0.057 \mathrm{~g} / \mathrm{kg}$ total diet, and n-6/n-3 5:1); CG1 ( $0.6 \mathrm{~mL}$ blended oil, $6.1 \%$ palm oil, cholesterol of $0.04 \mathrm{~g} / \mathrm{kg}$ total diet, and n-6/n-3 9:1); CG2 (0.6 mL blended oil, 6.1\% palm oil, cholesterol of $0.057 \mathrm{~g} / \mathrm{kg}$ total diet, and $\mathrm{n}-6 / \mathrm{n}-3 \mathrm{9}: 1$ ). Different proportions of blended oil (g/100 g) for groups: EG1/EG2 (camellia oil $10 \mathrm{~g}$, sunflower oil 74 g, and linseed oil 16 g); EG3/EG4 (camellia oil 18.6 g, sunflower oil 53.5 g, and linseed oil 27.9 g); CG1/CG2 (camellia oil 10.2 g, sunflower oil $73.5 \mathrm{~g}$, and linseed oil $16.3 \mathrm{~g}$ ).

1.58 and $1.23 \mathrm{mmol} / \mathrm{L}$ of TC, respectively. Moreover, rats in EG3 taking low $\mathrm{n}-6 / \mathrm{n}-3$ ratio $(5: 1)$ and cholesterol $(0.04 \mathrm{~g} / \mathrm{kg}$ total diet) showed significantly decreased TC compared to those in EG2 taking high $\mathrm{n}-6 / \mathrm{n}-3$ ratio $(9: 1)$ and cholesterol $(0.057 \mathrm{~g} / \mathrm{kg}$ total diet $)$. From these results, it is clear that no matter the fat content in the diet, the higher cholesterol feeding might cause the higher plasma TC in rats. However, TC content in EG3 fed with $5: 1 \mathrm{n}-6 / \mathrm{n}-3$ was similar to that in EG1 fed with $9: 1 n-6 / n-3$, suggesting that $n-6 / n-3$ ratio of $5: 1$ could not reduce plasma TC levels.

The TG contents in EG1, EG2, EG3, and EG4 were $0.43,0.35,0.46$, and $0.38 \mathrm{mmol} / \mathrm{L}$, respectively. The data showed that, with the same fat energy (36.06\%) for EG2/EG4 and EG3, TG contents in EG2/EG4 fed with cholesterol of $0.057 \mathrm{~g} / \mathrm{kg}$ total diet were significantly lower $(P<0.05)$ than that in EG3 fed with cholesterol of $0.04 \mathrm{~g} / \mathrm{kg}$ total diet. However, TG contents in CG1 (cholesterol of $0.04 \mathrm{~g} / \mathrm{kg}$ total diet) and CG2 (cholesterol of $0.057 \mathrm{~g} / \mathrm{kg}$ total diet), with the same fat energy of $30 \%$, were 0.45 and $0.44 \mathrm{mmol} / \mathrm{L}$, respectively, showing no significant difference $(P>0.05)$. There is a possibility that increased intake of cholesterol under high-fat diet could reduce plasma TG.

The contents of LDL-C in EG1, EG2, EG3, EG4, CG1, and CG2 were $0.39,0.42,0.28,0.67,0.36$, and $0.39 \mathrm{mmol} / \mathrm{L}$, 
TABLE 7: The correlation analyses of biochemical indices (HDL-C/LDL-C, TC, TG, and LDL-C).

\begin{tabular}{lccc}
\hline Dependent variable & Independent variable & Correlation coefficient & $P$ value \\
\hline \multirow{2}{*}{ HDL-C/LDL-C } & TC & $-0.423^{* *}$ & 0.000 \\
& TG & $-0.539^{*}$ & 0.010 \\
TC & LDL-C & $-0.634^{* *}$ & 0.000 \\
& TG & $0.210^{*}$ & 0.042 \\
\hline${ }^{*} P$ LDL-C & $-0.253^{*}$ & 0.013 \\
\hline
\end{tabular}

${ }^{* *} P$ lower than $0.01\left({ }^{* *} P<0.01\right)$ was very significantly different, and ${ }^{*} P$ lower than $0.05\left({ }^{* *} P<0.05\right)$ was significantly different; TC, total cholesterol; TG, triacylglycerols; VLDL-C, very low density lipoprotein cholesterol; HDL-C, high density lipoprotein cholesterol; LDL-C, low density lipoprotein cholesterol.

respectively. The level of LDL-C in EG4 (cholesterol of $0.057 \mathrm{~g} / \mathrm{kg}$ total diet $)$ was significantly higher $(P<0.05)$ compared to that in EG3/EG1 (cholesterol of $0.04 \mathrm{~g} / \mathrm{kg}$ total diet). It can be inferred that the increasing cholesterol content in diet could increase level of LDL-C in plasma.

With the same n-6/n-3 $(9: 1)$ in EG1/EG2, the content of HDL-C in both was $0.61 \mathrm{mmol} / \mathrm{L}$, showing no significant differences $(P>0.05)$. Similarly, the contents of HDL-C in CG1 and CG2 $(9: 1 \mathrm{n}-6 / \mathrm{n}-3)$ were 0.54 and $0.50 \mathrm{mmol} / \mathrm{L}$, respectively, showing no significant differences $(P>0.05)$. However, it was 0.63 and $0.99 \mathrm{mmol} / \mathrm{L}$ in EG3 and EG4 $(5: 1$ $\mathrm{n}-6 / \mathrm{n}-3)$, respectively, which were higher than those in EG1, EG2, CG1, and CG2 $(9: 1 n-6 / n-3)$. Results indicated that the HDL-C level increased with the increase of $n-3$ PUFAs in the diet.

Furthermore, HDL-C/TC were decreased significantly $(P<0.05)$ in all groups after treatments. Besides, except for EG3, the ratios of HDL-C/LDL-C were also reduced significantly $(P<0.05)$ in all groups after treatments. With n-6/n-3 ratio of $9: 1$, fat energy of $36.06 \%$ in EG1 and EG2, or $30 \%$ in CG1 and CG2, there was no significant difference in HDL-C/LDL-C. However, with the same fat energy of $36.06 \%$ and $n-6 / n-3$ ratio of $5: 1$, the rats in EG3 fed with cholesterol of $0.04 \mathrm{~g} / \mathrm{kg}$ total diet showed significantly higher ratio of HDL-C/LDL-C $(2.24 \pm 0.26)$ than EG4 fed with cholesterol of $0.057 \mathrm{~g} / \mathrm{kg}$ total diet $(1.53 \pm 0.26)$. Besides, under high-fat diet (36.06\%), the ratios in EG4 (1.53 \pm $0.26)$ were relatively higher than in EG2 $(1.47 \pm 0.29)$, but significantly higher in EG3 $(2.24 \pm 0.26)$ than in EG1 $(1.52 \pm 0.26)$, respectively, at the same level of cholesterol, difference in $n-6 / n-3$ with 9 or 5 . Moreover, rats in EG3 taking low $\mathrm{n}-6 / \mathrm{n}-3$ ratio $(5: 1)$ and cholesterol $(0.04 \mathrm{~g} / \mathrm{kg}$ total diet) showed significantly increased HDL-C/LDL-C and HDL-C/TC compared to those in EG2 taking high n-6/n3 ratio $(9: 1)$ and cholesterol $(0.057 \mathrm{~g} / \mathrm{kg}$ total diet). These results demonstrated that decreased ratio of $n-6 / n-3$ in diet could increase the ratio of HDL-C/LDL-C in plasma of rats under high-fat diet, and the increase level was significant accompanying low cholesterol feeding.

As shown in Table 7, negative correlations were found between HDL-C/LDL-C and TC $(-0.423,0.000)$, between HDL-C/LDL-C and LDL-C $(-0.634,0.000)$, between HDLC/LDL-C and TG $(-0.539,0.010)$, and between TC and LDLC $(-0.253,0.013)$. Besides, a negative correlation $(-0.679$, $0.031)$ was detected between HDL-C and BWs only in EG3 (not shown in the table). However, there was a positive correlation between TC and TG $(0.210,0.042)$.
3.3. Effects of Dietary Fat and Cholesterol on FA Compositions in Plasma. The FAs profile in the diet could affect the FA compositions in rats' plasma (Table 8 ). When the $n-6 / n-3$ PUFA ratio in the diet decreased (EG 3 and 4 ), the proportion of n-3 PUFA in plasma increased, thus resulting in the decrease of n-6/n-3 PUFA ratio. Besides, rats fed with n-6/n-3 ratio of 9:1 (EG 1 and 2; CG 1 and 2) had significantly higher level of arachidonic acid (ARA) in the plasma compared to that in rats fed with n-6/n-3 ratio of $5: 1$ (EG 3 and 4). Moreover, the proportions of eicosapentaenoic acid (EPA) and docosahexaenoic acid (DHA) in rats feeding $n-6 / n-3$ ratio of 5:1 (EG 3 and 4) were higher than those in rats feeding n-6/n-3 ratio of 9:1 (EG 1 and 2; CG 1 and 2). Cholesterol in diet can also affect the FA compositions in plasma. Rats fed with higher cholesterol $(0.057 \mathrm{~g} / \mathrm{kg}$ total diet $)$ increased the TMUFAs (mainly oleic acid), but decreased the TSFAs (mainly stearic acid) compared to those in rats feeding cholesterol of $0.04 \mathrm{~g} / \mathrm{kg}$ total diet. Further, rats in EG3 taking low $\mathrm{n}-6 / \mathrm{n}-3$ ratio $(5: 1)$ and cholesterol $(0.04 \mathrm{~g} / \mathrm{kg}$ total diet) showed higher EPA and DHA and lower ARA compared to those in EG2 taking high n-6/n-3 ratio $(9: 1)$ and cholesterol $(0.057 \mathrm{~g} / \mathrm{kg}$ total diet $)$.

3.4. Effects of Dietary Fat and Cholesterol on FA Compositions in Liver and Muscle. The FA compositions in rats' liver and muscle are shown in Table 9. In liver, rats fed with lower n6/n-3 ratio of $5: 1$ (EG 3 and 4) had significantly higher level of n-3 PUFA (mainly of ALA) and lower ratio of $n-6 / n-3$ compared to rats fed with n-6/n-3 ratio of $9: 1$ (EG 1 and 2; CG 1 and 2). Similarly, the changes of n-3 PUFA and n6/n-3 ratio in muscle showed the same tendency with liver. Interestingly, the concentrations of $\alpha$-linolenic acid (ALA) in liver and muscle were higher than those in plasma, brain, and heart tissues. However, traces of EPA and DHA were registered in muscle compared to those in other organs.

\subsection{Effects of Dietary Fat and Cholesterol on FA Compositions} in Brain and Heart. The FAs compositions in rats' brain and heart are presented in Table 10. Brain, a unique organ, can accumulate high concentration of DHA because this fatty acid plays a vital role in development and function of nervous system. In this study, ALA in brain was significantly metabolized to DHA as evidenced by the DHA levels in six groups varied from $11.49 \%$ to $13.66 \%$. Interestingly, $\mathrm{n}$ 6/n-3 ratios in six groups were approximately with value of $1: 1$. Rats in groups fed with different cholesterol of 0.057 or $0.04 \mathrm{~g} / \mathrm{kg}$ total diet showed no obvious change of FA 
TABLE 8: Main fatty acid compositions (\% area) in rats' plasma after 60 days' treatment.

\begin{tabular}{|c|c|c|c|c|c|c|}
\hline Fatty acids & EG1 & EG2 & EG3 & EG4 & CG1 & CG2 \\
\hline 14:0 & $0.21 \pm 0.06^{\mathrm{ab}}$ & $0.20 \pm 0.07^{\mathrm{ab}}$ & $0.16 \pm 0.06^{\mathrm{a}}$ & $0.21 \pm 0.04^{\mathrm{b}}$ & $0.21 \pm 0.04^{\mathrm{ab}}$ & $0.23 \pm 0.06^{\mathrm{b}}$ \\
\hline $16: 0$ & $21.32 \pm 2.08^{\mathrm{ab}}$ & $22.06 \pm 1.07^{\mathrm{ac}}$ & $21.61 \pm 1.10^{\mathrm{ab}}$ & $20.72 \pm 2.7^{\mathrm{a}}$ & $23.21 \pm 1.0^{c}$ & $22.68 \pm 1.0^{\mathrm{bc}}$ \\
\hline 9c16:1 & $0.21 \pm 0.05^{\mathrm{a}}$ & $0.16 \pm 0.08^{\mathrm{a}}$ & $0.15 \pm 0.03^{\mathrm{a}}$ & $0.18 \pm 0.05^{\mathrm{a}}$ & $0.16 \pm 0.04^{\mathrm{a}}$ & $0.46 \pm 0.40^{\mathrm{b}}$ \\
\hline 18:0 & $18.62 \pm 2.3^{c}$ & $17.40 \pm 1.31^{\mathrm{c}}$ & $19.20 \pm 3.14^{c}$ & $13.38 \pm 4.24^{\mathrm{a}}$ & $16.29 \pm 2.50^{b c}$ & $14.63 \pm 1.94^{\mathrm{ab}}$ \\
\hline $9 t 18: 1$ & $0.10 \pm 0.02^{\mathrm{b}}$ & $0.11 \pm 0.06^{\mathrm{b}}$ & $0.10 \pm 0.01^{\mathrm{b}}$ & $0.10 \pm 0.02^{\mathrm{b}}$ & $0.08 \pm 0.01^{\mathrm{a}}$ & $0.09 \pm 0.01^{\mathrm{ab}}$ \\
\hline $9 \mathrm{c} 18: 1 \mathrm{OA}$ & $9.30 \pm 3.06^{\mathrm{a}}$ & $10.77 \pm 1.61^{\mathrm{a}}$ & $11.14 \pm 3.05^{\mathrm{a}}$ & $13.38 \pm 1.94^{\mathrm{c}}$ & $11.46 \pm 2.29^{\mathrm{ab}}$ & $13.53 \pm 2.41^{b c}$ \\
\hline 11c18:1 & $1.21 \pm 0.22^{\mathrm{a}}$ & $1.53 \pm 0.31^{\mathrm{b}}$ & $1.12 \pm 0.24^{\mathrm{a}}$ & $1.65 \pm 0.27^{\mathrm{b}}$ & $1.76 \pm 0.42^{\mathrm{bc}}$ & $1.97 \pm 0.32^{c}$ \\
\hline $9 \mathrm{c} 12 \mathrm{c} 18: 2 \mathrm{LA}$ & $19.47 \pm 3.76^{\mathrm{a}}$ & $20.59 \pm 7.03^{\mathrm{a}}$ & $25.10 \pm 1.56^{\mathrm{b}}$ & $25.23 \pm 3.22^{\mathrm{b}}$ & $24.53 \pm 1.92^{b}$ & $25.13 \pm 2.15^{\mathrm{b}}$ \\
\hline $20: 0$ & $0.21 \pm 0.06^{\mathrm{c}}$ & $0.19 \pm 0.02^{b c}$ & $0.17 \pm 0.02^{b}$ & $0.16 \pm 0.02^{b}$ & $0.13 \pm 0.02^{\mathrm{a}}$ & $0.13 \pm 0.04^{\mathrm{a}}$ \\
\hline $18: 3 n-6$ & $0.13 \pm 0.06^{\mathrm{ab}}$ & $0.11 \pm 0.01^{\mathrm{a}}$ & $0.17 \pm 0.07^{b c}$ & $0.17 \pm 0.09^{b c}$ & $0.15 \pm 0.04^{\mathrm{abc}}$ & $0.19 \pm 0.06^{c}$ \\
\hline $5 c 20: 1$ & $0.25 \pm 0.04^{\mathrm{b}}$ & $0.25 \pm 0.04^{\mathrm{b}}$ & $0.17 \pm 0.05^{\mathrm{a}}$ & $0.20 \pm 0.05^{\mathrm{a}}$ & $0.20 \pm 0.07^{\mathrm{a}}$ & $0.18 \pm 0.02^{\mathrm{a}}$ \\
\hline 11c20:1 & $0.27 \pm 0.12^{\mathrm{a}}$ & $0.36 \pm 0.10^{\mathrm{a}}$ & $0.65 \pm 0.25^{\mathrm{a}}$ & $1.66 \pm 2.09^{\mathrm{b}}$ & $0.44 \pm 0.18^{\mathrm{a}}$ & $0.61 \pm 0.20^{\mathrm{a}}$ \\
\hline 18:3n-3 ALA & $0.39 \pm 0.08^{\mathrm{ab}}$ & $0.39 \pm 0.08^{\mathrm{ab}}$ & $0.43 \pm 0.05^{\mathrm{ab}}$ & $0.47 \pm 0.10^{b}$ & $0.35 \pm 0.06^{\mathrm{a}}$ & $0.38 \pm 0.04^{\mathrm{ab}}$ \\
\hline $20: 2 n-6$ & $0.35 \pm 0.07^{\mathrm{c}}$ & $0.35 \pm 0.05^{\mathrm{bc}}$ & $0.23 \pm 0.06^{\mathrm{a}}$ & $0.31 \pm 0.07^{\mathrm{bc}}$ & $0.36 \pm 0.10^{c}$ & $0.29 \pm 0.03^{b}$ \\
\hline $22: 0$ & $0.11 \pm 0.06^{\mathrm{b}}$ & $0.06 \pm 0.01^{\mathrm{a}}$ & $0.07 \pm 0.03^{\mathrm{ab}}$ & $0.16 \pm 0.05^{\mathrm{c}}$ & $0.18 \pm 0.04^{c}$ & $0.16 \pm 0.03^{c}$ \\
\hline $20: 4 n-6$ ARA & $9.67 \pm 1.90^{\mathrm{bc}}$ & $11.08 \pm 1.89^{c}$ & $7.45 \pm 1.72^{\mathrm{a}}$ & $7.87 \pm 1.83^{\mathrm{a}}$ & $10.03 \pm 1.82^{\mathrm{c}}$ & $9.65 \pm 1.75^{\mathrm{bc}}$ \\
\hline $22: 2 n-6$ & $0.37 \pm 0.08^{\mathrm{ab}}$ & $0.37 \pm 0.23^{\mathrm{ab}}$ & $0.26 \pm 0.07^{\mathrm{a}}$ & $0.37 \pm 0.13^{b}$ & $0.33 \pm 0.10^{\mathrm{ab}}$ & $0.31 \pm 0.09^{\mathrm{ab}}$ \\
\hline 20:5n-3 EPA & $0.28 \pm 0.02^{\mathrm{a}}$ & $0.39 \pm 0.06^{\mathrm{b}}$ & $0.52 \pm 0.05^{\mathrm{cd}}$ & $0.62 \pm 0.09^{\mathrm{d}}$ & $0.42 \pm 0.05^{\mathrm{bc}}$ & $0.49 \pm 0.06^{b c}$ \\
\hline $24: 0$ & $0.11 \pm 0.05^{\mathrm{b}}$ & $0.06 \pm 0.03^{\mathrm{a}}$ & $0.05 \pm 0.02^{\mathrm{a}}$ & $0.06 \pm 0.02^{\mathrm{a}}$ & $0.05 \pm 0.01^{\mathrm{a}}$ & $0.04 \pm 0.01^{\mathrm{a}}$ \\
\hline $22: 3 n-3$ & $0.52 \pm 0.23^{\mathrm{b}}$ & $0.56 \pm 0.13^{\mathrm{b}}$ & $0.57 \pm 0.36^{\mathrm{b}}$ & $0.56 \pm 0.28^{b}$ & $0.38 \pm 0.26^{\mathrm{ab}}$ & $0.18 \pm 0.04^{\mathrm{a}}$ \\
\hline $22: 4 n-6$ & $0.27 \pm 0.04^{\mathrm{d}}$ & $0.25 \pm 0.05^{\mathrm{cd}}$ & $0.15 \pm 0.05^{\mathrm{a}}$ & $0.19 \pm 0.05^{\mathrm{ab}}$ & $0.19 \pm 0.05^{\mathrm{ab}}$ & $0.22 \pm 0.05^{b c}$ \\
\hline $22: 5 n-6$ & $0.68 \pm 0.15^{b c}$ & $0.69 \pm 0.20^{b c}$ & $0.74 \pm 0.24^{b c}$ & $0.82 \pm 0.19^{c}$ & $0.66 \pm 0.15^{\mathrm{b}}$ & $0.34 \pm 0.11^{\mathrm{a}}$ \\
\hline $22: 5 n-3$ DPA & $0.50 \pm 0.23$ & $0.51 \pm 0.16$ & $0.67 \pm 0.27$ & $0.54 \pm 0.12$ & $0.45 \pm 0.26$ & $0.58 \pm 0.18$ \\
\hline 22:6n-3 DHA & $3.29 \pm 0.42^{\mathrm{ac}}$ & $3.36 \pm 0.33^{\mathrm{ac}}$ & $3.72 \pm 0.69^{c}$ & $3.51 \pm 0.71^{b c}$ & $3.02 \pm 0.18^{\mathrm{a}}$ & $3.07 \pm 0.22^{\mathrm{ab}}$ \\
\hline TSFAs & $41.33 \pm 3.21^{b c}$ & $40.82 \pm 1.30^{\mathrm{bc}}$ & $41.87 \pm 2.67^{\mathrm{c}}$ & $35.55 \pm 2.23^{\mathrm{a}}$ & $40.95 \pm 2.47^{b c}$ & $38.55 \pm 2.90^{\mathrm{ab}}$ \\
\hline TMUFAs & $11.48 \pm 3.45^{\mathrm{a}}$ & $13.41 \pm 1.78^{\mathrm{ab}}$ & $13.50 \pm 3.34^{\mathrm{ab}}$ & $17.78 \pm 2.89^{\mathrm{d}}$ & $14.25 \pm 2.81^{b c}$ & $17.01 \pm 2.84^{\mathrm{cd}}$ \\
\hline TPUFAs & $41.50 \pm 1.09$ & $40.20 \pm 2.35$ & $42.30 \pm 1.40$ & $42.49 \pm 1.45$ & $42.61 \pm 1.15$ & $42.20 \pm 1.08$ \\
\hline n-6 PUFAs & $36.51 \pm 1.14^{\mathrm{a}}$ & $36.97 \pm 1.21^{\mathrm{ab}}$ & $36.49 \pm 1.26^{\mathrm{a}}$ & $36.79 \pm 1.01^{\mathrm{a}}$ & $37.95 \pm 1.18^{c}$ & $37.37 \pm 1.29^{b c}$ \\
\hline n-3 PUFAs & $4.99 \pm 0.69^{\mathrm{a}}$ & $5.23 \pm 0.54^{\mathrm{ab}}$ & $5.80 \pm 0.99^{b}$ & $5.70 \pm 0.99^{b}$ & $4.66 \pm 0.72^{\mathrm{a}}$ & $4.83 \pm 0.64^{\mathrm{a}}$ \\
\hline$n-6 / n-3$ ratio & $7.32 \pm 0.12^{\mathrm{b}}$ & $7.07 \pm 0.18^{\mathrm{ab}}$ & $6.29 \pm 0.13^{\mathrm{a}}$ & $6.45 \pm 0.10^{\mathrm{a}}$ & $8.14 \pm 0.19^{c}$ & $7.72 \pm 0.15^{\mathrm{bc}}$ \\
\hline $\mathrm{S} / \mathrm{M} / \mathrm{P}$ & $1.09: 0.30: 1$ & $1.01: 0.33: 1$ & $1: 0.32: 1.01$ & $1: 0.50: 1.19$ & $1: 0.35: 1.04$ & $1: 0.44: 1.09$ \\
\hline
\end{tabular}

Values presented as means $(n=12) \pm$ SD. Mean values within each row followed by different letters $(\mathrm{a}, \mathrm{b}, \mathrm{c}$, etc.) are significantly $(P<0.05)$ different. OA, oleic acid; LA, linoleic acid; ALA, alpha-linolenic acid; EPA, eicosapntemacnioc acid; ARA, arachidonic acid; DPA, docosapentaenoic acid; DHA, docosahexenoic acid; TSFAs, total saturated fatty acids, the sum of $(\mathrm{C} 14: 0+\mathrm{C} 16: 0+\mathrm{C} 18: 0+\mathrm{C} 20: 0+\mathrm{C} 22: 0+\mathrm{C} 24: 0+\cdots)$; TMUFAs, total monounsaturated fatty acids, the sum of $(\mathrm{C} 16: 1+\mathrm{C} 18: 1+\mathrm{C} 20: 1+\cdots)$; TPUFAs, total polyunsaturated fatty acids, the sum of $(\mathrm{C} 18: 2 n-6+\mathrm{C} 18: 3 n-6+\mathrm{C} 18: 3 n-3+\mathrm{C} 20: 2 n-6+20: 4 n-6+C 22: 2 n-$ $6+$ C20:5n-3 + C22:3n-3 + C22:4n-6 + C22:5n-6 + C22:5n-3 + C22:6n-3 + - ); S/M/P: TSFA/TMUFA/TPUFA. Different dietary treatments for groups: EG1 ( $0.8 \mathrm{~mL}$ blended oil, $9 \%$ palm oil, cholesterol of $0.04 \mathrm{~g} / \mathrm{kg}$ total diet, and $\mathrm{n}-6 / \mathrm{n}-39: 1)$; EG2 (0.8 mL blended oil, $9 \%$ palm oil, cholesterol of $0.057 \mathrm{~g} / \mathrm{kg}$ total diet, and n-6/n-3 9:1); EG3 (0.8 mL blended oil, 8.6\% palm oil, cholesterol of $0.04 \mathrm{~g} / \mathrm{kg}$ total diet, and n-6/n-3 5:1); EG4 (0.8 mL blended oil, $8.6 \%$ palm oil, cholesterol of $0.057 \mathrm{~g} / \mathrm{kg}$ total diet, and n-6/n-3 5:1); CG1 (0.6 mL blended oil, $6.1 \%$ palm oil, cholesterol of $0.04 \mathrm{~g} / \mathrm{kg}$ total diet, and n-6/n-3 9:1); CG2 (0.6 mL blended oil, 6.1\% palm oil, cholesterol of $0.057 \mathrm{~g} / \mathrm{kg}$ total diet, and n-6/n-3 9:1). Different proportions of blended oil (g/100 g) for groups: EG1/EG2 (camellia oil $10 \mathrm{~g}$, sunflower oil $74 \mathrm{~g}$, and linseed oil 16 g); EG3/EG4 (camellia oil 18.6 g, sunflower oil 53.5 g, and linseed oil 27.9 g); CG1/CG2 (camellia oil 10.2 g, sunflower oil $73.5 \mathrm{~g}$, and linseed oil $16.3 \mathrm{~g}$ ).

compositions. Also, rats in EG3 taking low $n-6 / n-3$ ratio $(5: 1)$ and cholesterol $(0.04 \mathrm{~g} / \mathrm{kg}$ total diet $)$ showed no significant differences in EPA and DHA and n-6/n-3 ratio compared to those in EG2 taking high n-6/n-3 ratio $(9: 1)$ and cholesterol $(0.057 \mathrm{~g} / \mathrm{kg}$ total diet $)$.

Heart also showed high DHA levels in six groups changing from $12.18 \%$ to $13.25 \%$. Besides, the ARA level in heart changed from $15.33 \%$ to $18.08 \%$, higher than those in plasma, liver, brain, and muscle. However, traces of ALA were registered in heart. Similar to the results in plasma, rats fed with n-6/n-3 ratio of 9:1 (EG 1 and 2; CG 1 and 2) had higher level of ARA in the heart compared to that in rats fed with n-6/n-3 ratio of $5: 1$ (EG 3 and 4 ). And the higher cholesterol $(0.057 \mathrm{~g} / \mathrm{kg}$ total diet $)$ in diet also increased the total monounsaturated fatty acid (mainly oleic acid) but decreased the total saturated fatty acids (mainly stearic acid) in heart compared to those in rats feeding cholesterol of $0.04 \mathrm{~g} / \mathrm{kg}$ total diet. 
TABLE 9: Fatty acid compositions (\% area) in rats' liver and muscle after 60 days' treatment.

\begin{tabular}{|c|c|c|c|c|c|c|}
\hline Fatty acids & EG1 & EG2 & EG3 & EG4 & CG1 & CG2 \\
\hline \multicolumn{7}{|c|}{ Fatty acid compositions ( $\%$ area) in rats' liver } \\
\hline $16: 0$ & $17.41 \pm 1.08^{\mathrm{a}}$ & $18.19 \pm 1.54^{\mathrm{ab}}$ & $17.72 \pm 0.82^{\mathrm{a}}$ & $17.69 \pm 2.90^{\mathrm{a}}$ & $19.59 \pm 1.86^{\mathrm{b}}$ & $18.67 \pm 0.90^{\mathrm{ab}}$ \\
\hline $9 \mathrm{cl} 6: 1$ & $0.43 \pm 0.19^{\mathrm{a}}$ & $0.58 \pm 0.36^{\mathrm{bc}}$ & $0.40 \pm 0.12^{\mathrm{a}}$ & $0.61 \pm 0.37^{\mathrm{bc}}$ & $0.78 \pm 0.52^{\mathrm{c}}$ & $0.50 \pm 0.31^{\mathrm{ab}}$ \\
\hline 18:0 & $6.41 \pm 1.42^{\mathrm{ab}}$ & $6.49 \pm 1.42^{\mathrm{ab}}$ & $6.51 \pm 2.08^{\mathrm{ab}}$ & $7.02 \pm 5.66^{\mathrm{ab}}$ & $4.92 \pm 2.42^{\mathrm{a}}$ & $7.77 \pm 3.51^{\mathrm{b}}$ \\
\hline $9 t 18: 1$ & $0.23 \pm 0.02$ & $0.23 \pm 0.02$ & $0.24 \pm 0.02$ & $0.23 \pm 0.04$ & $0.23 \pm 0.02$ & $0.22 \pm 0.02$ \\
\hline 11t18:1 & $0.19 \pm 0.02^{\mathrm{a}}$ & $0.19 \pm 0.02^{\mathrm{a}}$ & $0.22 \pm 0.02^{\mathrm{b}}$ & $0.20 \pm 0.04^{\mathrm{ab}}$ & $0.18 \pm 0.01^{\mathrm{a}}$ & $0.19 \pm 0.02^{\mathrm{a}}$ \\
\hline 9c18:1 OA & $25.09 \pm 2.40^{\mathrm{ab}}$ & $25.02 \pm 1.43^{\mathrm{ab}}$ & $24.79 \pm 2.40^{\mathrm{ab}}$ & $25.06 \pm 6.57^{\mathrm{ab}}$ & $27.15 \pm 3.79^{\mathrm{b}}$ & $23.15 \pm 4.52^{\mathrm{a}}$ \\
\hline 11c18:1 & $1.29 \pm 0.18^{\mathrm{ab}}$ & $1.37 \pm 0.30^{\mathrm{b}}$ & $1.07 \pm 0.13^{\mathrm{a}}$ & $1.37 \pm 0.32^{\mathrm{b}}$ & $1.69 \pm 0.38^{\mathrm{c}}$ & $1.45 \pm 0.33^{\mathrm{b}}$ \\
\hline $9 \mathrm{cl} 2 \mathrm{c} 18: 2 \mathrm{LA}$ & $30.58 \pm 1.33^{\mathrm{ab}}$ & $29.47 \pm 1.80^{\mathrm{ab}}$ & $31.00 \pm 1.32^{\mathrm{b}}$ & $29.07 \pm 2.47^{\mathrm{a}}$ & $30.08 \pm 2.28^{\mathrm{a}}$ & $29.59 \pm 2.54^{\mathrm{ab}}$ \\
\hline $20: 0$ & $0.11 \pm 0.02^{\mathrm{b}}$ & $0.10 \pm 0.03^{\mathrm{ab}}$ & $0.10 \pm 0.03^{\mathrm{ab}}$ & $0.11 \pm 0.03^{\mathrm{b}}$ & $0.09 \pm 0.02^{\mathrm{a}}$ & $0.11 \pm 0.33^{\mathrm{b}}$ \\
\hline $18: 3 n-6$ & $0.41 \pm 0.10^{\mathrm{a}}$ & $0.39 \pm 0.06^{\mathrm{a}}$ & $0.77 \pm 0.23^{\mathrm{b}}$ & $0.40 \pm 0.07^{\mathrm{a}}$ & $0.37 \pm 0.07^{\mathrm{a}}$ & $0.36 \pm 0.08^{\mathrm{a}}$ \\
\hline $11 \mathrm{c} 20: 1$ & $0.48 \pm 0.10^{c}$ & $0.43 \pm 0.11^{\mathrm{bc}}$ & $0.28 \pm 0.09^{\mathrm{a}}$ & $0.35 \pm 0.11^{\mathrm{ab}}$ & $0.43 \pm 0.13^{b c}$ & $0.36 \pm 0.11^{\mathrm{ab}}$ \\
\hline 18:3n-3 ALA & $1.40 \pm 0.18^{\mathrm{a}}$ & $1.43 \pm 0.28^{\mathrm{a}}$ & $3.19 \pm 0.82^{\mathrm{b}}$ & $2.80 \pm 0.92^{\mathrm{b}}$ & $1.45 \pm 0.23^{\mathrm{a}}$ & $1.12 \pm 0.33^{\mathrm{a}}$ \\
\hline $20: 2 n-6$ & $0.54 \pm 0.12^{\mathrm{d}}$ & $0.48 \pm 0.10^{\mathrm{cd}}$ & $0.27 \pm 0.10^{\mathrm{a}}$ & $0.38 \pm 0.08^{\mathrm{b}}$ & $0.49 \pm 0.14^{\mathrm{cd}}$ & $0.40 \pm 0.07^{b c}$ \\
\hline $22: 0$ & $0.04 \pm 0.01$ & $0.04 \pm 0.01$ & $0.04 \pm 0.02$ & $0.05 \pm 0.02$ & $0.04 \pm 0.01$ & $0.05 \pm 0.01$ \\
\hline $20: 3 n-6$ & $1.27 \pm 0.22^{\mathrm{c}}$ & $1.20 \pm 0.20^{\mathrm{bc}}$ & $1.57 \pm 0.24^{\mathrm{d}}$ & $1.00 \pm 0.18^{\mathrm{b}}$ & $0.99 \pm 0.16^{\mathrm{a}}$ & $1.04 \pm 0.25^{\mathrm{ab}}$ \\
\hline $20: 3 n-3$ & $0.04 \pm 0.01$ & $0.04 \pm 0.00^{\mathrm{ab}}$ & $0.05 \pm 0.01^{b}$ & $0.07 \pm 0.03^{\mathrm{c}}$ & $0.05 \pm 0.01^{b}$ & $0.03 \pm 0.01^{\mathrm{a}}$ \\
\hline $20: 4 n-6$ ARA & $5.31 \pm 0.55^{\mathrm{bc}}$ & $5.70 \pm 0.70^{c}$ & $3.93 \pm 0.80^{\mathrm{a}}$ & $4.31 \pm 0.53^{\mathrm{ab}}$ & $5.68 \pm 0.71^{\mathrm{c}}$ & $6.15 \pm 0.73^{\mathrm{c}}$ \\
\hline 20:5n-3 EPA & $0.54 \pm 0.06^{\mathrm{a}}$ & $0.53 \pm 0.05^{\mathrm{a}}$ & $0.74 \pm 0.07^{\mathfrak{c}}$ & $0.70 \pm 0.05^{\mathfrak{c}}$ & $0.53 \pm 0.08^{\mathrm{a}}$ & $0.61 \pm 0.05^{\mathrm{ab}}$ \\
\hline $22: 3 n-3$ & $0.22 \pm 0.06^{\mathrm{ab}}$ & $0.28 \pm 0.16^{\mathrm{ac}}$ & $0.21 \pm 0.15^{\mathrm{a}}$ & $0.32 \pm 0.09^{\mathrm{ac}}$ & $0.34 \pm 0.18^{b c}$ & $0.36 \pm 0.15^{\mathrm{c}}$ \\
\hline $22: 4 n-6$ & $0.46 \pm 0.12^{\mathrm{d}}$ & $0.36 \pm 0.08^{\mathrm{c}}$ & $0.21 \pm 0.08^{\mathrm{a}}$ & $0.24 \pm 0.06^{\mathrm{ab}}$ & $0.31 \pm 0.08^{\mathrm{bc}}$ & $0.33 \pm 0.10^{c}$ \\
\hline $22: 5 n-6$ & $0.18 \pm 0.05^{\mathrm{b}}$ & $0.16 \pm 0.04^{\mathrm{ab}}$ & $0.14 \pm 0.05^{\mathrm{ab}}$ & $0.13 \pm 0.07^{\mathrm{a}}$ & $0.13 \pm 0.03^{\mathrm{a}}$ & $0.12 \pm 0.03^{\mathrm{a}}$ \\
\hline $22: 5 n-3$ DPA & $1.23 \pm 0.27$ & $1.09 \pm 0.22$ & $1.07 \pm 0.29$ & $1.16 \pm 0.32$ & $1.04 \pm 0.18$ & $1.17 \pm 0.37$ \\
\hline 22:6n-3 DHA & $3.93 \pm 0.43$ & $3.96 \pm 0.61$ & $3.38 \pm 0.57$ & $3.68 \pm 0.73$ & $3.08 \pm 0.72$ & $3.85 \pm 0.99$ \\
\hline TSFAs & $24.70 \pm 1.40^{\mathrm{a}}$ & $25.75 \pm 1.22^{\mathrm{ab}}$ & $25.12 \pm 2.33^{\mathrm{a}}$ & $25.56 \pm 3.16^{\mathrm{ab}}$ & $25.47 \pm 2.71^{\mathrm{ab}}$ & $27.32 \pm 3.24^{\mathrm{b}}$ \\
\hline TMUFAs & $27.74 \pm 2.62^{\mathrm{ab}}$ & $27.84 \pm 1.81^{\mathrm{ab}}$ & $27.00 \pm 2.43^{\mathrm{ab}}$ & $27.86 \pm 6.78^{\mathrm{ab}}$ & $30.45 \pm 4.42^{\mathrm{b}}$ & $25.89 \pm 5.02^{\mathrm{a}}$ \\
\hline TPUFAs & $46.25 \pm 2.18^{\mathrm{b}}$ & $45.07 \pm 2.21^{\mathrm{ab}}$ & $46.18 \pm 1.17^{\mathrm{b}}$ & $45.10 \pm 4.52^{\mathrm{ab}}$ & $42.74 \pm 3.21^{\mathrm{a}}$ & $45.54 \pm 2.78^{b}$ \\
\hline n-6 PUFAs & $38.91 \pm 1.68^{b}$ & $37.75 \pm 1.78^{\mathrm{ab}}$ & $37.94 \pm 0.96^{\mathrm{ab}}$ & $36.46 \pm 3.07^{\mathrm{a}}$ & $36.27 \pm 2.52^{\mathrm{a}}$ & $38.41 \pm 1.99^{b}$ \\
\hline n-3 PUFAs & $7.35 \pm 0.61^{b c}$ & $7.32 \pm 0.60^{\mathrm{bc}}$ & $8.63 \pm 0.57^{\mathrm{d}}$ & $8.63 \pm 1.59^{\mathrm{d}}$ & $6.48 \pm 0.82^{\mathrm{a}}$ & $7.13 \pm 1.04^{\mathrm{ab}}$ \\
\hline n- $6 / n-3$ ratio & $5.32 \pm 0.34^{\mathrm{bc}}$ & $5.17 \pm 0.30^{\mathrm{b}}$ & $4.40 \pm 0.33^{\mathrm{a}}$ & $4.28 \pm 0.43^{\mathrm{a}}$ & $5.64 \pm 0.46^{c}$ & $5.50 \pm 0.86^{b c}$ \\
\hline $\mathrm{S} / \mathrm{M} / \mathrm{P}$ & $1: 1.12: 1.67$ & $1: 1.08: 1.75$ & $1: 1.07: 1.84$ & $1: 1.09: 1.76$ & $1: 1.20: 1.68$ & $1: 0.95: 1.67$ \\
\hline \multicolumn{7}{|c|}{ Fatty acid compositions (\% area) in rats' muscle } \\
\hline $16: 0$ & $23.30 \pm 1.90^{\mathrm{bd}}$ & $22.45 \pm 1.62^{\mathrm{ab}}$ & $22.06 \pm 0.90^{\mathrm{a}}$ & $22.64 \pm 1.2^{\mathrm{ac}}$ & $24.00 \pm 1.05^{\mathrm{d}}$ & $23.74 \pm 1.22^{\mathrm{cd}}$ \\
\hline 18:0 & $4.05 \pm 2.42$ & $3.96 \pm 1.28$ & $4.04 \pm 0.69$ & $3.52 \pm 0.86$ & $4.00 \pm 1.36$ & $4.07 \pm 0.64$ \\
\hline $9 \mathrm{c} 18: 1 \mathrm{OA}$ & $32.57 \pm 7.02$ & $33.96 \pm 4.12$ & $35.12 \pm 2.12$ & $35.90 \pm 2.33$ & $34.28 \pm 3.84$ & $34.04 \pm 2.35$ \\
\hline 11c18:1 & $2.10 \pm 0.34^{\mathrm{c}}$ & $2.17 \pm 0.19^{c}$ & $1.57 \pm 0.15^{\mathrm{a}}$ & $1.75 \pm 0.11^{\mathrm{ab}}$ & $1.68 \pm 0.78^{\mathrm{a}}$ & $2.02 \pm 0.11^{\mathrm{bc}}$ \\
\hline $9 \mathrm{c} 12 \mathrm{c} 18: 2 \mathrm{LA}$ & $24.81 \pm 2.04^{\mathrm{cd}}$ & $25.28 \pm 2.45^{\mathrm{d}}$ & $22.64 \pm 1.77^{\mathrm{ab}}$ & $21.42 \pm 1.51^{\mathrm{a}}$ & $22.08 \pm 2.04^{\mathrm{a}}$ & $23.16 \pm 1.92^{\mathrm{bc}}$ \\
\hline $18: 3 n-6$ & $0.03 \pm 0.01$ & $0.03 \pm 0.01$ & $0.04 \pm 0.01$ & $0.03 \pm 0.01$ & $0.03 \pm 0.01$ & $0.03 \pm 0.01$ \\
\hline $18: 3 n-3$ ALA & $1.42 \pm 0.29^{\mathrm{a}}$ & $1.40 \pm 0.22^{\mathrm{a}}$ & $2.93 \pm 0.56^{c}$ & $2.53 \pm 0.4^{\mathrm{b}}$ & $1.27 \pm 0.24^{\mathrm{a}}$ & $1.28 \pm 0.20^{\mathrm{a}}$ \\
\hline $20: 2 n-6$ & $0.15 \pm 0.26$ & $0.08 \pm 0.01$ & $0.07 \pm 0.01$ & $0.07 \pm 0.01$ & $0.07 \pm 0.02$ & $0.07 \pm 0.01$ \\
\hline $20: 3 n-6$ & $0.25 \pm 0.26^{\mathrm{b}}$ & $0.20 \pm 0.15^{\mathrm{ab}}$ & $0.22 \pm 0.11^{\mathrm{ab}}$ & $0.12 \pm 0.08^{\mathrm{ab}}$ & $0.17 \pm 0.14^{\mathrm{ab}}$ & $0.09 \pm 0.07^{\mathrm{a}}$ \\
\hline $20: 4 n-6$ ARA & $1.34 \pm 0.47$ & $1.60 \pm 0.46$ & $1.16 \pm 0.40$ & $0.90 \pm 0.10$ & $1.63 \pm 0.16$ & $1.50 \pm 0.41$ \\
\hline $20: 5 n-3 \mathrm{EPA}$ & $0.05 \pm 0.04$ & $0.06 \pm 0.02$ & $0.06 \pm 0.02$ & $0.05 \pm 0.03$ & $0.06 \pm 0.04$ & $0.06 \pm 0.02$ \\
\hline $22: 4 n-6$ & $0.07 \pm 0.07$ & $0.06 \pm 0.05$ & $0.04 \pm 0.02$ & $0.04 \pm 0.04$ & $0.05 \pm 0.05$ & $0.04 \pm 0.02$ \\
\hline $22: 5 n-3$ DPA & $0.12 \pm 0.07$ & $0.19 \pm 0.06$ & $0.21 \pm 0.07$ & $0.17 \pm 0.03$ & $0.16 \pm 0.07$ & $0.18 \pm 0.04$ \\
\hline 22:6n-3 DHA & $0.76 \pm 0.26$ & $0.80 \pm 0.20$ & $0.88 \pm 0.23$ & $0.90 \pm 0.24$ & $0.81 \pm 0.29$ & $0.75 \pm 0.27$ \\
\hline
\end{tabular}


TABLE 9: Continued.

\begin{tabular}{lcccccc}
\hline Fatty acids & EG1 & EG2 & EG3 & EG4 & CG1 \\
\hline TSFAs & $28.73 \pm 4.01^{\mathrm{ab}}$ & $27.87 \pm 2.45^{\mathrm{ab}}$ & $27.61 \pm 1.40^{\mathrm{a}}$ & $27.67 \pm 1.50^{\mathrm{a}}$ & $29.62 \pm 1.87^{\mathrm{b}}$ & $29.43 \pm 1.45^{\mathrm{ab}}$ \\
TMUFAs & $38.76 \pm 3.18^{\mathrm{a}}$ & $40.02 \pm 4.41^{\mathrm{ab}}$ & $42.85 \pm 2.03^{\mathrm{bc}}$ & $44.41 \pm 3.11^{\mathrm{c}}$ & $42.17 \pm 4.81^{\mathrm{ac}}$ & $41.71 \pm 3.08^{\mathrm{ac}}$ \\
TPUFAs & $28.92 \pm 2.89$ & $29.87 \pm 2.60$ & $28.33 \pm 1.78$ & $26.14 \pm 2.99$ & $26.38 \pm 3.73$ & $27.17 \pm 2.95$ \\
n-6 PUFAs & $26.56 \pm 2.84^{\mathrm{bc}}$ & $27.35 \pm 2.79^{\mathrm{c}}$ & $24.21 \pm 1.52^{\mathrm{ab}}$ & $22.60 \pm 2.40^{\mathrm{a}}$ & $24.03 \pm 2.06^{\mathrm{ab}}$ & $24.91 \pm 1.39^{\mathrm{ab}}$ \\
n-3 PUFAs & $2.32 \pm 0.23^{\mathrm{a}}$ & $2.45 \pm 0.22^{\mathrm{a}}$ & $4.10 \pm 0.22^{\mathrm{b}}$ & $3.51 \pm 0.23^{\mathrm{b}}$ & $2.29 \pm 0.16^{\mathrm{a}}$ & $2.22 \pm 0.17^{\mathrm{a}}$ \\
n-6/n-3 ratio & $11.43 \pm 1.62^{\mathrm{b}}$ & $11.15 \pm 1.58^{\mathrm{b}}$ & $5.91 \pm 1.26^{\mathrm{a}}$ & $6.44 \pm 1.66^{\mathrm{a}}$ & $10.47 \pm 1.70^{\mathrm{b}}$ & $11.23 \pm 1.48^{\mathrm{b}}$ \\
S/M/P & $1: 1.35: 1.0$ & $1: 1.44: 1.07$ & $1: 1.55: 1.02$ & $1: 1.60: 0.94$ & $1: 1.42: 0.89$ & $1: 1.42: 0.92$ \\
\hline
\end{tabular}

Values presented as means $(n=12) \pm$ SD. Mean values within each row followed by different letters $(\mathrm{a}, \mathrm{b}, \mathrm{c}$, etc.) are significantly $(P<0.05)$ different. OA, oleic acid; LA, linoleic acid; ALA, alpha-linolenic acid; EPA, eicosapntemacnioc acid; ARA, arachidonic acid; DPA, docosapentaenoic acid; DHA, docosahexenoic acid; TSFAs, total saturated fatty acids, the sum of $(\mathrm{C} 16: 0+\mathrm{C} 18: 0+\mathrm{C} 20: 0+\mathrm{C} 22: 0+\cdots)$; TMUFAs, total monounsaturated fatty acids, the sum of $(\mathrm{C} 16: 1+$ $\mathrm{C} 18: 1+\mathrm{C} 20: 1+\mathrm{C} 22: 1+\mathrm{C} 24: 1+\cdots) ;$ TPUFAs, total polyunsaturated fatty acids, the sum of $(\mathrm{C} 18: 2 \mathrm{n}-6+\mathrm{C} 18: 3 \mathrm{n}-3+\mathrm{C} 20: 2 \mathrm{n}-6+\mathrm{C} 20: 3 \mathrm{n}-6+\mathrm{C} 20: 4 \mathrm{n}-6+\mathrm{C} 22: 2 \mathrm{n}-$ $6+$ C20:5n-3 + C22:4n-6 + C22:5n-6 + C22:5n-3 + 22:6n-3 + - ) $)$ S/M/P: TSFAs/TMUFAs/TPUFAs. Different dietary treatments for groups: EG1 (0.8 mL blended oil, $9 \%$ palm oil, cholesterol of $0.04 \mathrm{~g} / \mathrm{kg}$ total diet, and n-6/n-3 9:1); EG2 (0.8 mL blended oil, $9 \%$ palm oil, cholesterol of $0.057 \mathrm{~g} / \mathrm{kg}$ total diet, and $\mathrm{n}-6 / \mathrm{n}-39: 1)$; EG3 ( $0.8 \mathrm{~mL}$ blended oil, $8.6 \%$ palm oil, cholesterol of $0.04 \mathrm{~g} / \mathrm{kg}$ total diet, and n-6/n-3 $5: 1)$; EG4 (0.8 mL blended oil, $8.6 \%$ palm oil, cholesterol of $0.057 \mathrm{~g} / \mathrm{kg}$ total diet, and n-6/n-3 5:1); CG1 (0.6 mL blended oil, 6.1\% palm oil, cholesterol of $0.04 \mathrm{~g} / \mathrm{kg}$ total diet, and n-6/n-3 9:1); CG2 (0.6 mL blended oil, 6.1\% palm oil, cholesterol of $0.057 \mathrm{~g} / \mathrm{kg}$ total diet, and $\mathrm{n}-6 / \mathrm{n}-39$ : 1 ). Different proportions of blended oil (g/100 g) for groups: EG1/EG2 (camellia oil $10 \mathrm{~g}$, sunflower oil $74 \mathrm{~g}$, and linseed oil $16 \mathrm{~g}$ ); EG3/EG4 (camellia oil 18.6 g, sunflower oil 53.5 g, and linseed oil 27.9 g); CG1/CG2 (camellia oil 10.2 g, sunflower oil $73.5 \mathrm{~g}$, and linseed oil $16.3 \mathrm{~g})$.

\section{Discussion}

Dietary modification has led to an imbalance in the $n-6 / n-$ 3 PUFA ratio with an increase in $n-6$ FAs but a marked reduction in n-3 FAs in diets, resulting in a high $n-6 / n-3$ PUFA ratio [17]. The $n-6 / n-3$ PUFA ratio of $9: 1$ in today's typical Chinese diets is quite different from the $n-6 / n-3$ PUFA ratio of $1: 1$, which was found in human diets many years ago [18]. Therefore, there is necessity to investigate the effects of Chinese dietary pattern of fat content, n-6/n-3 ratio, and cholesterol content on lipid profile and FA compositions in plasma and tissues using a rat model.

Results showed that high-fat diet contributed to the increasing BWs of rats. However, rats fed with high fat, modulating by cholesterol level of $0.04 \mathrm{~g} / \mathrm{kg}$ total diet and n-6/n-3 ratio of $5: 1$, showed significant decrease in BWs compared to those of rat fed with cholesterol of $0.057 \mathrm{~g} / \mathrm{kg}$ total diet and $n-6 / n-3$ ratio of $9: 1$, which indicated that, even under high-fat diet, the increase of rat's BWs could be controlled by simultaneously keeping cholesterol and n-6/n3 at low levels. Supporting our results, Buckley and Howe [19] reported that a dietary intake of n-3 PUFAs may reduce BWs in obese rats and body fat accumulation, specifically visceral fat of rats fed with a high-fat diet. Guelzim et al. [20] showed that n-3 PUFAs could improve the body composition and insulin sensitivity and resulted in rats' weight loss. Haimeur et al. [21] also found that rats fed with high-fat diet had higher adiposity and adipose tissue/BW ratio compared to those in the control group, but these values were reduced by a dietary supplementation of n-3 PUFA.

The plasma levels of TC, TG, HDL-C, and LDL-C in rats varied with diet. The higher cholesterol fed under high-fat diet, the higher TC and LDL-C levels, and the lower TG in rats' plasma. However, under high-fat diet, the HDL-C level and the ratios of HDL-C/LDL-C and HDL-C/TC in rats' plasma increased in response to simultaneous intake of low n-6/n-3 (5:1) and cholesterol (0.04 g/kg total diet) compared to those of rats fed with high cholesterol of $0.057 \mathrm{~g} / \mathrm{kg}$ total diet and $n-6 / n-3$ ratio of $9: 1$. The result was in concurrence with an earlier report that cholesterol feeding in rats could significantly increase the plasma cholesterol levels, whereas it could reduce the levels of plasma TG and phospholipids [11]. Moreover, in our study, we found that, under highfat diet, the decreased ratio of n-6/n-3 (5:1) in diet could not reduce plasma TC levels, which was different from the results of Jeffery et al. [22] reporting a decreased serum cholesterol concentrations as the n-6/n-3 PUFA ratio in the diet decreased. It has been reported that the incidence of atherosclerosis [23] and cardiovascular disease [24] was in close correlation with the high levels of TC, TG, and LDL-C. On the contrary, a high level of HDL-C was cardioprotective [25]. Moreover, among the possible mechanisms that may contribute to the cardiovascular benefits, n-3 PUFAs other than n-6 PUFAs were found to have the ability of decreasing the contents of TG and LDL-C with moderate increase in the level of HDL-C [26-28]. Thus, our study suggested that the decreased levels of TC, TG, and LDL-C and the increased levels of HDL-C/LDL-C and HDL-C/TC after the simultaneous intakes of low cholesterol $(0.04 \mathrm{~g} / \mathrm{kg}$ total diet $)$ and n-6/n-3 (5:1) may be in favor of reducing the incidence of associated metabolic diseases.

Besides, we found that the accumulation of various FAs was associated with the dietary intake of $n-6 / n-3$ ratio, cholesterol, and even tissues. Although the blended oils fed to rats were with no EPA and DHA, these two PUFAs were detected in rats' plasma and four organs, especially high in brain and heart. This is because dietary ALA can convert into long-chain n-3 PUFA, such as EPA, DPA, and DHA due to the desaturation, elongation, and $\beta$-oxidation reactions $[29,30]$. Increased levels of EPA, DHA, and ALA and decreased level of ARA were observed in rats' plasma after the intake of n6/n-3 (5:1) and cholesterol ( $0.04 \mathrm{~g} / \mathrm{kg}$ total diet) compared to 
TABLE 10: Fatty acid compositions (\% area) in rats' brain and heart after 60 days' treatment.

\begin{tabular}{|c|c|c|c|c|c|c|}
\hline Fatty acids & EG1 & EG2 & EG3 & EG4 & CG1 & CG2 \\
\hline \multicolumn{7}{|c|}{ Fatty acid compositions ( $\%$ area) in rats' brain } \\
\hline $16: 00$ & $21.53 \pm 1.35$ & $21.68 \pm 1.16$ & $21.36 \pm 0.76$ & $21.48 \pm 1.05$ & $21.09 \pm 1.06$ & $20.83 \pm 0.79$ \\
\hline $9 \mathrm{c} 16: 1$ & $0.38 \pm 0.03^{\mathrm{ab}}$ & $0.34 \pm 0.03^{\mathrm{a}}$ & $0.37 \pm 0.04^{\mathrm{ab}}$ & $0.36 \pm 0.04^{\mathrm{ab}}$ & $0.38 \pm 0.03^{b}$ & $0.38 \pm 0.03^{\mathrm{b}}$ \\
\hline 18:00 & $20.69 \pm 0.60^{\mathrm{a}}$ & $21.31 \pm 0.46^{\mathrm{b}}$ & $20.45 \pm 0.52^{\mathrm{a}}$ & $20.51 \pm 0.56^{\mathrm{a}}$ & $20.54 \pm 0.42^{\mathrm{a}}$ & $20.46 \pm 0.44^{\mathrm{a}}$ \\
\hline 9t18:1 & $0.18 \pm 0.04^{\mathrm{b}}$ & $0.13 \pm 0.12^{\mathrm{a}}$ & $0.14 \pm 0.03^{\mathrm{a}}$ & $0.14 \pm 0.02^{\mathrm{a}}$ & $0.16 \pm 0.03^{\mathrm{ab}}$ & $0.19 \pm 0.04^{\mathrm{b}}$ \\
\hline $9 \mathrm{c} 18: 1 \mathrm{OA}$ & $20.01 \pm 1.26^{\mathrm{ab}}$ & $19.22 \pm 1.26^{\mathrm{a}}$ & $19.95 \pm 1.01^{\mathrm{ab}}$ & $20.64 \pm 1.11^{\mathrm{b}}$ & $20.85 \pm 1.05^{\mathrm{bc}}$ & $21.68 \pm 1.12^{\mathrm{c}}$ \\
\hline 11c18:1 & $3.86 \pm 0.36^{\mathrm{abc}}$ & $3.78 \pm 0.31^{\mathrm{ab}}$ & $3.73 \pm 0.28^{\mathrm{a}}$ & $4.04 \pm 0.38^{\mathrm{bc}}$ & $4.15 \pm 0.31^{\mathrm{c}}$ & $4.14 \pm 0.33^{c}$ \\
\hline $9 \mathrm{cl} 2 \mathrm{c} 18: 2 \mathrm{LA}$ & $1.20 \pm 0.24^{\mathrm{a}}$ & $1.08 \pm 0.11^{\mathrm{a}}$ & $1.45 \pm 0.27^{\mathrm{b}}$ & $1.15 \pm 0.23^{\mathrm{a}}$ & $1.13 \pm 0.08^{\mathrm{a}}$ & $1.13 \pm 0.16^{\mathrm{a}}$ \\
\hline $20: 00$ & $0.40 \pm 0.10^{b c}$ & $0.29 \pm 0.09^{\mathrm{a}}$ & $0.34 \pm 0.08^{\mathrm{ab}}$ & $0.34 \pm 0.08^{\mathrm{ab}}$ & $0.39 \pm 0.09^{b c}$ & $0.44 \pm 0.10^{c}$ \\
\hline $5 c 20: 1$ & $0.06 \pm 0.02^{\mathrm{ab}}$ & $0.05 \pm 0.01^{\mathrm{a}}$ & $0.04 \pm 0.01^{\mathrm{a}}$ & $0.05 \pm 0.00^{\mathrm{ab}}$ & $0.05 \pm 0.01^{\mathrm{ab}}$ & $0.06 \pm 0.01^{b}$ \\
\hline 11c20:1 & $2.18 \pm 0.69^{\mathrm{ab}}$ & $1.73 \pm 0.62^{\mathrm{a}}$ & $2.13 \pm 0.58^{\mathrm{ab}}$ & $2.18 \pm 0.64^{\mathrm{ab}}$ & $2.34 \pm 0.59^{\mathrm{b}}$ & $2.50 \pm 0.64^{b}$ \\
\hline $18: 3 n-3$ ALA & $0.60 \pm 0.18$ & $0.54 \pm 0.16$ & $0.57 \pm 0.15$ & $0.59 \pm 0.11$ & $0.65 \pm 0.16$ & $0.69 \pm 0.15$ \\
\hline $20: 2 n-6$ & $0.23 \pm 0.05^{b c}$ & $0.19 \pm 0.04^{\mathrm{a}}$ & $0.26 \pm 0.04^{c}$ & $0.23 \pm 0.06^{b c}$ & $0.22 \pm 0.04^{\mathrm{b}}$ & $0.21 \pm 0.03^{\mathrm{ab}}$ \\
\hline $22: 00$ & $0.28 \pm 0.05^{\mathrm{bc}}$ & $0.23 \pm 0.06^{\mathrm{a}}$ & $0.24 \pm 0.04^{\mathrm{ab}}$ & $0.24 \pm 0.03^{\mathrm{ab}}$ & $0.29 \pm 0.06^{\mathrm{cd}}$ & $0.33 \pm 0.05^{\mathrm{d}}$ \\
\hline $20: 3 n-6$ & $0.47 \pm 0.02^{\mathrm{ab}}$ & $0.45 \pm 0.03^{\mathrm{a}}$ & $0.63 \pm 0.03^{c}$ & $0.47 \pm 0.03^{\mathrm{ab}}$ & $0.48 \pm 0.04^{\mathrm{b}}$ & $0.46 \pm 0.03^{\mathrm{ab}}$ \\
\hline $22: \ln -9$ & $0.24 \pm 0.07^{b c}$ & $0.18 \pm 0.06^{\mathrm{a}}$ & $0.22 \pm 0.06^{\mathrm{ab}}$ & $0.21 \pm 0.04^{\mathrm{ab}}$ & $0.25 \pm 0.06^{b c}$ & $0.27 \pm 0.06^{\mathrm{c}}$ \\
\hline $20: 4 n-6$ ARA & $9.87 \pm 0.55^{\mathrm{ab}}$ & $10.28 \pm 0.48^{\mathrm{b}}$ & $9.81 \pm 0.46^{\mathrm{a}}$ & $9.66 \pm 0.66^{\mathrm{a}}$ & $9.53 \pm 0.54^{\mathrm{a}}$ & $9.45 \pm 0.51^{\mathrm{a}}$ \\
\hline $22: 2 n-6$ & $0.07 \pm 0.05^{\mathrm{ab}}$ & $0.04 \pm 0.02^{\mathrm{a}}$ & $0.06 \pm 0.04^{\mathrm{ab}}$ & $0.06 \pm 0.02^{\mathrm{ab}}$ & $0.08 \pm 0.03^{\mathrm{b}}$ & $0.08 \pm 0.03^{b}$ \\
\hline 20:5n-3 EPA & $0.23 \pm 0.04^{\mathrm{ab}}$ & $0.19 \pm 0.03^{\mathrm{a}}$ & $0.23 \pm 0.04^{\mathrm{ab}}$ & $0.22 \pm 0.02^{\mathrm{ab}}$ & $0.24 \pm 0.05^{b c}$ & $0.27 \pm 0.06^{\mathrm{c}}$ \\
\hline $24: 1 n-9$ & $0.12 \pm 0.04^{\mathrm{ab}}$ & $0.10 \pm 0.03^{\mathrm{a}}$ & $0.11 \pm 0.02$ & $0.11 \pm 0.01^{\mathrm{ab}}$ & $0.13 \pm 0.03^{b c}$ & $0.15 \pm 0.05^{\mathrm{c}}$ \\
\hline $22: 4 n-6$ & $2.86 \pm 0.19$ & $2.81 \pm 0.20$ & $2.73 \pm 0.19$ & $2.76 \pm 0.22$ & $2.75 \pm 0.19$ & $2.77 \pm 0.16$ \\
\hline $22: 5 n-6$ & $0.48 \pm 0.08^{c}$ & $0.47 \pm 0.12^{c}$ & $0.31 \pm 0.04^{\mathrm{a}}$ & $0.38 \pm 0.07^{\mathrm{b}}$ & $0.39 \pm 0.06^{\mathrm{b}}$ & $0.43 \pm 0.07^{\mathrm{bc}}$ \\
\hline $22: 5 n-3$ DPA & $0.17 \pm 0.02^{\mathrm{ab}}$ & $0.15 \pm 0.01^{\mathrm{a}}$ & $0.22 \pm 0.02^{c}$ & $0.18 \pm 0.02^{\mathrm{b}}$ & $0.16 \pm 0.02^{\mathrm{a}}$ & $0.17 \pm 0.03^{\mathrm{ab}}$ \\
\hline 22:6n-3 DHA & $12.69 \pm 1.00^{b c}$ & $13.66 \pm 0.96^{\mathrm{d}}$ & $13.26 \pm 0.99^{\mathrm{cd}}$ & $12.66 \pm 0.73^{b c}$ & $12.34 \pm 0.86^{\mathrm{b}}$ & $11.49 \pm 0.95^{\mathrm{a}}$ \\
\hline TSFAs & $43.33 \pm 1.34^{\mathrm{ab}}$ & $43.91 \pm 1.33^{\mathrm{b}}$ & $42.87 \pm 0.93^{\mathrm{a}}$ & $43.00 \pm 1.10^{\mathrm{ab}}$ & $42.76 \pm 1.18^{\mathrm{a}}$ & $42.53 \pm 1.06^{\mathrm{a}}$ \\
\hline TMUFAs & $27.08 \pm 2.33^{\mathrm{ab}}$ & $25.61 \pm 2.21^{\mathrm{a}}$ & $26.79 \pm 1.88^{\mathrm{ab}}$ & $27.82 \pm 2.12^{\mathrm{bc}}$ & $28.41 \pm 1.99^{\mathrm{bc}}$ & $29.47 \pm 2.02^{c}$ \\
\hline TPUFAs & $28.99 \pm 1.24^{\mathrm{bc}}$ & $29.94 \pm 1.09^{c}$ & $29.71 \pm 1.12^{\mathrm{c}}$ & $28.56 \pm 1.13^{\mathrm{b}}$ & $28.18 \pm 1.16^{\mathrm{ab}}$ & $27.37 \pm 1.17^{\mathrm{a}}$ \\
\hline n-6 PUFAs & $15.16 \pm 0.57^{\mathrm{bc}}$ & $15.33 \pm 0.48^{c}$ & $15.27 \pm 0.48^{\mathrm{c}}$ & $14.74 \pm 0.67^{\mathrm{ab}}$ & $14.60 \pm 0.66^{\mathrm{a}}$ & $14.54 \pm 0.58^{\mathrm{a}}$ \\
\hline n-3 PUFAs & $13.83 \pm 0.76^{\mathrm{bc}}$ & $14.67 \pm 0.78^{\mathrm{d}}$ & $14.44 \pm 0.79^{\mathrm{cd}}$ & $13.82 \pm 0.5^{\mathrm{b}}$ & $13.58 \pm 0.62^{\mathrm{b}}$ & $12.83 \pm 0.74^{\mathrm{a}}$ \\
\hline n-6/n-3 ratio & $1.10 \pm 0.04^{b c}$ & $1.04 \pm 0.05^{\mathrm{a}}$ & $1.06 \pm 0.05^{\mathrm{ab}}$ & $1.06 \pm 0.03^{\mathrm{ab}}$ & $1.07 \pm 0.04^{\mathrm{ab}}$ & $1.13 \pm 0.05^{\mathrm{c}}$ \\
\hline $\mathrm{S} / \mathrm{M} / \mathrm{P}$ & $1.49: 0.93: 1$ & $1.47: 0.86: 1$ & $1.44: 0.90: 1$ & $1.51: 0.97: 1$ & $1.52: 1.00: 1$ & $1.55: 1.08: 1$ \\
\hline \multicolumn{7}{|c|}{ Fatty acid compositions ( $\%$ area) in rats' heart } \\
\hline $16: 00$ & $12.68 \pm 1.03^{\mathrm{bc}}$ & $12.18 \pm 0.33^{\mathrm{ab}}$ & $13.13 \pm 0.71^{\mathrm{c}}$ & $11.92 \pm 0.88^{\mathrm{a}}$ & $12.50 \pm 0.54^{\mathrm{b}}$ & $12.11 \pm 0.53^{\mathrm{ab}}$ \\
\hline $9 \mathrm{cl} 6: 1$ & $0.29 \pm 0.54$ & $0.11 \pm 0.05$ & $0.13 \pm 0.05$ & $0.14 \pm 0.08$ & $0.15 \pm 0.07$ & $0.11 \pm 0.04$ \\
\hline 18:00 & $22.41 \pm 1.62^{\mathrm{b}}$ & $23.28 \pm 0.56^{\mathrm{c}}$ & $20.90 \pm 0.85^{\mathrm{a}}$ & $23.29 \pm 0.76^{\mathrm{c}}$ & $22.47 \pm 0.62^{\mathrm{b}}$ & $22.93 \pm 0.94^{\mathrm{bc}}$ \\
\hline 9t18:1 & $0.15 \pm 0.02^{\mathrm{b}}$ & $0.14 \pm 0.01^{\mathrm{b}}$ & $0.18 \pm 0.02^{c}$ & $0.14 \pm 0.02^{\mathrm{b}}$ & $0.12 \pm 0.01^{\mathrm{a}}$ & $0.12 \pm 0.01^{\mathrm{a}}$ \\
\hline $9 \mathrm{cl} 8: 1 \mathrm{OA}$ & $6.22 \pm 2.34^{\mathrm{bc}}$ & $5.02 \pm 0.75^{\mathrm{a}}$ & $6.41 \pm 1.30^{\mathrm{c}}$ & $5.65 \pm 1.34^{\mathrm{ac}}$ & $5.27 \pm 0.93^{\mathrm{ab}}$ & $5.18 \pm 0.86^{\mathrm{ab}}$ \\
\hline 11c18:1 & $2.21 \pm 0.14^{\mathrm{b}}$ & $2.18 \pm 0.06^{\mathrm{b}}$ & $1.99 \pm 0.13^{\mathrm{a}}$ & $2.27 \pm 0.21^{\mathrm{b}}$ & $2.52 \pm 0.12$ & $2.49 \pm 0.14^{\mathrm{c}}$ \\
\hline $9 \mathrm{cl} 2 \mathrm{c} 18: 2 \mathrm{LA}$ & $20.37 \pm 1.40^{\mathrm{a}}$ & $20.82 \pm 0.95^{\mathrm{a}}$ & $25.48 \pm 2.39^{\mathrm{b}}$ & $21.27 \pm 1.90^{\mathrm{a}}$ & $21.47 \pm 1.30^{\mathrm{a}}$ & $20.96 \pm 0.92^{\mathrm{a}}$ \\
\hline $20: 00$ & $0.17 \pm 0.02^{b c}$ & $0.18 \pm 0.02^{\mathrm{cd}}$ & $0.20 \pm 0.04^{\mathrm{d}}$ & $0.20 \pm 0.04^{\mathrm{d}}$ & $0.16 \pm 0.01^{\mathrm{a}}$ & $0.14 \pm 0.01^{\mathrm{a}}$ \\
\hline $5 c 20: 1$ & $0.09 \pm 0.03^{\mathrm{ab}}$ & $0.09 \pm 0.01^{\mathrm{ab}}$ & $0.10 \pm 0.01^{b}$ & $0.09 \pm 0.01^{\mathrm{ab}}$ & $0.08 \pm 0.01^{\mathrm{a}}$ & $0.09 \pm 0.01^{\mathrm{a}}$ \\
\hline 11c20:1 & $0.16 \pm 0.06^{\mathrm{a}}$ & $0.14 \pm 0.03^{\mathrm{a}}$ & $0.40 \pm 0.10^{\mathrm{b}}$ & $0.27 \pm 0.07^{\mathrm{b}}$ & $0.14 \pm 0.03^{\mathrm{a}}$ & $0.14 \pm 0.06^{\mathrm{a}}$ \\
\hline $18: 3 n-3$ ALA & $0.18 \pm 0.07$ & $0.16 \pm 0.05$ & $0.14 \pm 0.04$ & $0.14 \pm 0.02$ & $0.16 \pm 0.02$ & $0.18 \pm 0.06^{\mathrm{a}}$ \\
\hline $20: 2 n-6$ & $0.20 \pm 0.02^{\mathrm{b}}$ & $0.19 \pm 0.02^{\mathrm{ab}}$ & $0.19 \pm 0.03^{\mathrm{ab}}$ & $0.19 \pm 0.02^{\mathrm{ab}}$ & $0.19 \pm 0.02^{\mathrm{ab}}$ & $0.18 \pm 0.01^{\mathrm{a}}$ \\
\hline $22: 00$ & $0.13 \pm 0.02^{\mathrm{cd}}$ & $0.12 \pm 0.02^{b c}$ & $0.15 \pm 0.03^{\mathrm{d}}$ & $0.14 \pm 0.04^{\mathrm{cd}}$ & $0.10 \pm 0.02^{\mathrm{ab}}$ & $0.09 \pm 0.01^{\mathrm{a}}$ \\
\hline $20: 3 n-3$ & $0.61 \pm 0.10^{\mathrm{a}}$ & $0.60 \pm 0.07^{\mathrm{a}}$ & $1.13 \pm 0.18^{\mathrm{b}}$ & $0.68 \pm 0.10^{\mathrm{a}}$ & $0.62 \pm 0.09^{\mathrm{a}}$ & $0.54 \pm 0.06^{\mathrm{a}}$ \\
\hline 20:4n-6 ARA & $18.01 \pm 0.66^{\mathrm{cd}}$ & $18.08 \pm 0.92^{\mathrm{d}}$ & $15.33 \pm 0.98^{\mathrm{a}}$ & $16.91 \pm 0.48^{\mathrm{ab}}$ & $17.27 \pm 0.86^{\mathrm{bc}}$ & $17.75 \pm 0.75^{\mathrm{bd}}$ \\
\hline 20:5n-3 EPA & $0.19 \pm 0.03^{\mathrm{a}}$ & $0.21 \pm 0.03^{\mathrm{a}}$ & $0.28 \pm 0.05^{\mathrm{b}}$ & $0.20 \pm 0.03^{\mathrm{a}}$ & $0.20 \pm 0.02^{\mathrm{a}}$ & $0.21 \pm 0.03$ \\
\hline $22: 4 n-6$ & $0.44 \pm 0.07^{\mathrm{b}}$ & $0.37 \pm 0.05^{\mathrm{a}}$ & $0.36 \pm 0.06^{\mathrm{a}}$ & $0.34 \pm 0.05^{\mathrm{a}}$ & $0.35 \pm 0.03^{\mathrm{a}}$ & $0.37 \pm 0.05^{\mathrm{a}}$ \\
\hline $22: 5 n-6$ & $0.34 \pm 0.08^{\mathrm{b}}$ & $0.32 \pm 0.03^{\mathrm{ab}}$ & $0.32 \pm 0.03^{\mathrm{ab}}$ & $0.29 \pm 0.04^{\mathrm{a}}$ & $0.30 \pm 0.04^{\mathrm{a}}$ & $0.29 \pm 0.03^{\mathrm{a}}$ \\
\hline $22: 5 n-3$ DPA & $0.69 \pm 0.60^{\mathrm{a}}$ & $1.83 \pm 0.27^{\mathrm{ab}}$ & $2.03 \pm 0.35^{\mathrm{b}}$ & $2.04 \pm 0.27^{\mathrm{b}}$ & $2.03 \pm 0.23^{b}$ & $2.03 \pm 0.32^{b}$ \\
\hline
\end{tabular}


TABLE 10: Continued.

\begin{tabular}{|c|c|c|c|c|c|c|}
\hline Fatty acids & EG1 & EG2 & EG3 & EG4 & CG1 & CG2 \\
\hline $22: 6 n-3$ DHA & $12.47 \pm 1.05^{\mathrm{ab}}$ & $13.03 \pm 0.83^{\mathrm{ab}}$ & $12.31 \pm 1.06^{\mathrm{ab}}$ & $12.18 \pm 1.25^{\mathrm{a}}$ & $13.25 \pm 1.15^{\mathrm{b}}$ & $13.11 \pm 1.00^{\mathrm{b}}$ \\
\hline TSFAs & $35.80 \pm 1.08^{\mathrm{b}}$ & $36.12 \pm 0.53^{\mathrm{b}}$ & $34.74 \pm 1.24^{\mathrm{a}}$ & $35.88 \pm 0.90^{\mathrm{b}}$ & $35.62 \pm 0.63^{b}$ & $35.66 \pm 0.85^{\mathrm{b}}$ \\
\hline TMUFAs & $9.25 \pm 2.81^{b}$ & $7.81 \pm 0.81^{\mathrm{a}}$ & $9.37 \pm 1.35^{\mathrm{b}}$ & $8.72 \pm 1.47^{\mathrm{ab}}$ & $8.40 \pm 1.10^{\mathrm{ab}}$ & $8.27 \pm 0.91^{\mathrm{ab}}$ \\
\hline TPUFAs & $54.35 \pm 2.09^{\mathrm{a}}$ & $55.61 \pm 0.53^{\mathrm{b}}$ & $55.50 \pm 1.31^{\mathrm{b}}$ & $55.01 \pm 1.42^{\mathrm{ab}}$ & $55.53 \pm 1.01^{\mathrm{b}}$ & $55.65 \pm 0.68^{b}$ \\
\hline n-6 PUFAs & $39.76 \pm 1.87^{\mathrm{a}}$ & $40.39 \pm 0.67^{\mathrm{a}}$ & $42.80 \pm 2.19^{b}$ & $40.45 \pm 1.63^{\mathrm{a}}$ & $39.88 \pm 1.49^{\mathrm{a}}$ & $40.10 \pm 1.02^{\mathrm{a}}$ \\
\hline n-3 PUFAs & $14.52 \pm 1.31^{\mathrm{b}}$ & $15.23 \pm 0.83^{b c}$ & $14.76 \pm 1.59^{\mathrm{a}}$ & $14.56 \pm 1.27^{\mathrm{b}}$ & $15.6 \pm 1.28^{c}$ & $15.53 \pm 0.84^{b c}$ \\
\hline n-6/n-3 ratio & $2.75 \pm 0.31^{\mathrm{a}}$ & $2.66 \pm 0.19^{\mathrm{a}}$ & $2.89 \pm 0.49^{b}$ & $2.80 \pm 0.32^{\mathrm{a}}$ & $2.57 \pm 0.32^{\mathrm{a}}$ & $2.59 \pm 0.19^{\mathrm{a}}$ \\
\hline $\mathrm{S} / \mathrm{M} / \mathrm{P}$ & $1: 0.26: 1.52$ & $1: 0.22: 1.54$ & $1: 0.27: 1.60$ & $1: 0.24: 1.53$ & $1: 0.24: 1.56$ & $1: 0.23: 0.56$ \\
\hline
\end{tabular}

Values presented as means $(n=12) \pm \mathrm{SD}$. Mean values within each row followed by different letters $(\mathrm{a}, \mathrm{b}, \mathrm{c}$, etc.) are significantly $(P<0.05)$ different. OA, oleic acid; LA, linoleic acid; ALA, alpha-linolenic acid; EPA, eicosapntemacnioc acid; ARA, arachidonic acid; DPA, docosapentaenoic acid; DHA, docosahexenoic acid; TSFAs, total saturated fatty acids, the sum of $(\mathrm{C} 16: 0+\mathrm{C} 18: 0+\mathrm{C} 20: 0+\mathrm{C} 22: 0+\cdots)$; TMUFAs, total monounsaturated fatty acids, the sum of $(\mathrm{C} 16: 1+$ $\mathrm{C} 18: 1+\mathrm{C} 20: 1+\cdots)$; TPUFAs, total polyunsaturated fatty acids, the sum of $(\mathrm{C} 18: 2 \mathrm{n}-6+\mathrm{C} 18: 3 \mathrm{n}-3+\mathrm{C} 20: 2 \mathrm{n}-6+\mathrm{C} 20: 3 \mathrm{n}-6+\mathrm{C} 20: 4 \mathrm{n}-6+\mathrm{C} 20: 5 \mathrm{n}-3+\mathrm{C} 22: 4 \mathrm{n}-$ $6+$ C22:5n-6 + C22:5n-3 + 22:6n-3 + - ) ) S/M/P: TSFAs/TMUFAs/TPUFAs. Different dietary treatments for groups: EG1 (0.8 mL blended oil, $9 \%$ palm oil, cholesterol of $0.04 \mathrm{~g} / \mathrm{kg}$ total diet, and n-6/n-3 9:1); EG2 (0.8 mL blended oil, $9 \%$ palm oil, cholesterol of $0.057 \mathrm{~g} / \mathrm{kg}$ total diet, and n-6/n-3 9:1); EG3 (0.8 mL blended oil, 8.6\% palm oil, cholesterol of $0.04 \mathrm{~g} / \mathrm{kg}$ total diet, and n-6/n-3 5:1); EG4 ( $0.8 \mathrm{~mL}$ blended oil, $8.6 \%$ palm oil, cholesterol of $0.057 \mathrm{~g} / \mathrm{kg}$ total diet, and $\mathrm{n}-6 / \mathrm{n}-35: 1)$; CG1 ( $0.6 \mathrm{~mL}$ blended oil, $6.1 \%$ palm oil, cholesterol of $0.04 \mathrm{~g} / \mathrm{kg}$ total diet, and n-6/n-3 9:1); CG2 (0.6 mL blended oil, $6.1 \%$ palm oil, cholesterol of $0.057 \mathrm{~g} / \mathrm{kg}$ total diet, and n-6/n-3 9:1). Different proportions of blended oil (g/100 g) for groups: EG1/EG2 (camellia oil $10 \mathrm{~g}$, sunflower oil $74 \mathrm{~g}$, and linseed oil $16 \mathrm{~g}$ ); EG3/EG4 (camellia oil 18.6 g, sunflower oil $53.5 \mathrm{~g}$, and linseed oil 27.9 g); CG1/CG2 (camellia oil 10.2 g, sunflower oil $73.5 \mathrm{~g}$, and linseed oil $16.3 \mathrm{~g}$ ).

rats fed with n-6/n-3 ratio of $9: 1$ and cholesterol of $0.057 \mathrm{~g} / \mathrm{kg}$ total diet. The result suggested that negative correlations were found between the levels of DHA, ALA, or EPA and ARA in plasma. This may be due to the antagonistic effect between DHA, ALA, or EPA and ARA in absorption and metabolism. Moreover, as the n-6/n-3 PUFA ratio of the diet decreased, the proportion of n-3 PUFA increased in plasma, liver, and muscle, thus resulting in the decreased $n-6 / n-3$ PUFA ratio. In accord with our results, Jeffery et al. [31] found that there were decreases in the levels of linoleic acid and ARA and an increase level of ALA in tissues as the n6/n-3 ratio of the diet decreased. Umesha and Naidu [32] reported that dietary feeding of blended oils with $n-6 / n-3$ ratio of 2.3-2.6 significantly increased ALA, EPA, and DHA content in serum, liver, and other tissues. We also found that the increasing cholesterol in diet increased the TMUFAs but decreased the TSFAs in rats' plasma and heart, which is in agreement with the results of Huang et al. [33] reporting an increase of 18:1n-9 after feeding rats with cholesterol. Therefore, due to the beneficial effect of n-3 PUFAs against n6 PUFAs on metabolism, it may be helpful to prevent diseases by controlling dietary intakes of $n-6 / n-3$ ratio (improving $n-3$ PUFAs) and cholesterol level at a low level.

\section{Conclusions}

High-fat diet increased the BWs of rats; however, the increase could be controlled by intakes of low cholesterol $(0.04 \mathrm{~g} / \mathrm{kg}$ total diet) and n-6/n-3 ratio (5:1). Besides, plasma lipid levels (TC and LDL-C) were also increased and HDL-C level was decreased under high-fat or high-cholesterol diet, but they were ameliorated in response to simultaneous intakes of low n-6/n-3 (5:1) and cholesterol (0.04 g/kg total diet). Likewise, the proportion of n-3 PUFA increased and the ratios of $n-6 / n-$ 3 decreased in plasma, liver, and muscle as the n-6/n-3 PUFA ratio in the diet decreased.

\section{Abbreviations}

BW: Body weight

PUFA: Polyunsaturated fatty acid

FAs: $\quad$ Fatty acids

TG: Triacylglycerols

TC: $\quad$ Total cholesterol

LDL-C: Low density lipoprotein cholesterol

HDL-C: High density lipoprotein cholesterol

VLDL-C: Very low density lipoprotein cholesterol

FAMEs: Fatty acid methyl esters

ARA: Arachidonic acid

EPA: Eicosapentaenoic acid

DHA: Docosahexaenoic acid

MUFA: Monounsaturated fatty acids

SFA: $\quad$ Saturated fatty acids

ALA: $\quad \alpha$-Linolenic acid.

\section{Conflicts of Interest}

The authors state that they have no conflicts of interest.

\section{Acknowledgments}

This study was supported by the National Key R\&D Program of China during the Thirteenth Five-Year Plan Period (2016YFD040140402) and the Research Program of Sate Key Laboratory of Food Science and Technology, Nanchang University (Project no. SKLF-ZZA-201610). The authors thank Experimental Animal Center of Jiangxi Medical College, Nanchang, Jiangxi, China, for animal care and help with sampling.

\section{References}

[1] R. P. Mensink and M. B. Katan, "Effect of dietary fatty acids on serum lipids and lipoproteins: a meta- analysis of 27 trials," 
Arteriosclerosis, Thrombosis, and Vascular Biology, vol. 12, no. 8, pp. 911-919, 1992.

[2] S. M. Grundy and M. A. Denke, "Dietary influences on serum lipids and lipoproteins," Journal of Lipid Research, vol. 31, no. 7, pp. 1149-1172, 1990.

[3] L. M. Li, K. Q. Rao, L. Z. Kong et al., "A description on the Chinese national nutrition and health survey in 2002," Chinese Journal of Epidemiology, vol. 26, no. 7, pp. 478-484, 2005 (Chinese).

[4] Y. N. He, F. Y. Zhai, Z. H. Wang, H. J. Wang, Y. S. Hu, and X. G. Yang, "The status and trend for dietary patten of energy, protein and fat in Chinese residents," Acta Nutrimenta Sinica, vol. 27, pp. 358-365, 2005 (Chinese).

[5] X. Q. Zhou, Z. Y. Deng, Y. H. Huang, and D. M. Liu, "Investigation of dietary fatty acids intakes of Chinese people during twenty years," Journal of Food Science and Biotechnology, vol. 27, no. 1, pp. 7-19, 2008 (Chinese).

[6] "Diet, Nutrition and the Prevention of Chronic Diseases, Report of a Joint WHO/FAO Expert Consultation," Tech. Rep. 916, World Health Organization, Geneva, Switzerland, 2003.

[7] C. C. Parrish, D. A. Pathy, and A. Angel, "Dietary fish oils limit adipose tissue hypertrophy in rats," Metabolism, vol. 39, no. 3, pp. 217-219, 1990.

[8] S. Wong, M. Reardon, and P. Nestel, "Reduced triglyceride formation from long-chain polyenoic fatty acids in rat hepatocytes," Metabolism, vol. 34, no. 10, pp. 900-905, 1985.

[9] S. Balasubramaniam, L. A. Simons, S. Chang, and J. B. Hickie, "Reduction in plasma cholesterol and increase in biliary cholesterol by a diet rich in n-3 fatty acids in the rat," Journal of Lipid Research, vol. 26, no. 6, pp. 684-689, 1985.

[10] L. G. Yang, Z. X. Song, H. Yin et al., "Low n-6/n-3 PUFA ratio improves lipid metabolism, inflammation, oxidative stress and endothelial function in rats using plant oils as n-3 fatty acid source," Lipids, vol. 51, no. 1, pp. 49-59, 2016.

[11] Y. S. Huang, B. A. Nassar, and D. F. Horrobin, "Changes of plasma lipids and long-chain n-3 and n-6 fatty acids in plasma, liver, heart and kidney phospholipids of rats fed variable levels of fish oil with or without cholesterol supplementation," Biochimica et Biophysica Acta (BBA) - Lipids and Lipid Metabolism, vol. 879, no. 1, pp. 22-27, 1986.

[12] Y.-F. Lu and H.-L. Wu, "Effect of Monounsaturated Fatty Acids under Fixed P/S and n-6/n-3 Ratios on Lipid Metabolism in Rats," Journal of Nutritional Science and Vitaminology, vol. 40, no. 2, pp. 189-200, 1994.

[13] C. A. Converse and E. R. Skinner, Lipoprotein Analysis: A Practical Approach, vol. 39, Oxford University Press, Oxford, UK, 1993.

[14] W. T. Friedewald, R. I. Levy, and D. S. Fredrickson, "Estimation of the concentration of low-density lipoprotein cholesterol in plasma, without use of the preparative ultracentrifuge," Clinical Chemistry, vol. 18, no. 6, pp. 499-502, 1972.

[15] J. Folch, M. Lees, and G. H. Sloane Stanley, "A simple method for the isolation and purification of total lipides from animal tissues," The Journal of Biological Chemistry, vol. 226, no. 1, pp. 497-509, 1957.

[16] L. Lei, J. Li, G.-Y. Li et al., "Stereospecific analysis of triacylglycerol and phospholipid fractions of five wild freshwater fish from poyang lake," Journal of Agricultural and Food Chemistry, vol. 60, no. 7, pp. 1857-1864, 2012.

[17] S. Eilat-Adar, M. Mete, A. Fretts et al., "Dietary patterns and their association with cardiovascular risk factors in a population undergoing lifestyle changes: the strong heart study," Nutrition, Metabolism and Cardiovascular Diseases, vol. 23, no. 6, pp. 528535, 2013.

[18] A. P. Simopoulos, "Evolutionary aspects of diet, the omega6/omega-3 ratio and genetic variation: nutritional implications for chronic diseases," Biomedicine \& Pharmacotherapy, vol. 60, no. 9, pp. 502-507, 2006.

[19] J. D. Buckley and P. R. C. Howe, "Anti-obesity effects of longchain omega-3 polyunsaturated fatty acids," Obesity Reviews, vol. 10, no. 6, pp. 648-659, 2009.

[20] N. Guelzim, J.-F. Huneau, V. Mathé et al., "N-3 fatty acids improve body composition and insulin sensitivity during energy restriction in the rat," Prostaglandins, Leukotrienes and Essential Fatty Acids, vol. 91, no. 5, pp. 203-211, 2014.

[21] A. Haimeur, V. Mimouni, L. Ulmann et al., "Fish oil and microalga omega-3 as dietary supplements: a comparative study on cardiovascular risk factors in high-fat fed rats," Lipids, vol. 51, no. 9, pp. 1037-1049, 2016.

[22] N. M. Jeffery, E. A. Newsholme, and P. C. Calder, "Level of polyunsaturated fatty acids and the n- 6 to $n-3$ polyunsaturated fatty acid ratio in the rat diet alter serum lipid levels and lymphocyte functions," Prostaglandins, Leukotrienes and Essential Fatty Acids, vol. 57, no. 2, pp. 149-160, 1997.

[23] M. Klagsbrun and E. R. Edelman, "Biological and biochemical properties of fibroblast growth factors. Implications for the pathogenesis of atherosclerosis," Arteriosclerosis, Thrombosis, and Vascular Biology, vol. 9, no. 3, pp. 269-278, 1989.

[24] S. M. Boekholdt, B. J. Arsenault, S. Mora et al., "Association of LDL cholesterol, non-HDL cholesterol, and apolipoprotein B levels with risk of cardiovascular events among patients treated with statins: a meta-analysis," The Journal of the American Medical Association, vol. 307, no. 12, pp. 1302-1309, 2012.

[25] T. Gordon, W. P. Castelli, M. C. Hjortland, W. B. Kannel, and T. R. Dawber, "High density lipoprotein as a protective factor against coronary heart disease. The Framingham study," American Journal of Medicine, vol. 62, no. 5, pp. 707-714, 1977.

[26] P. Benatti, G. Peluso, R. Nicolai, and M. Calvani, "Polyunsaturated fatty acids: biochemical, nutritional and epigenetic properties," Journal of the American College of Nutrition, vol. 23, no. 4, pp. 281-302, 2004.

[27] K. W. Lee and G. Y. H. Lip, "The role of omega-3 fatty acids in the secondary prevention of cardiovascular disease," QJM: $A n$ International Journal of Medicine, vol. 96, no. 7, pp. 465-480, 2003.

[28] U. N. Das, "Beneficial effect(s) of n-3 fatty acids in cardiovascular diseases: but, why and how?" Prostaglandins, Leukotrienes and Essential Fatty Acids, vol. 63, no. 6, pp. 351-362, 2000.

[29] J. T. Brenna, N. Salem Jr., A. J. Sinclair, and S. C. Cunnane, " $\alpha$-linolenic acid supplementation and conversion to n-3 longchain polyunsaturated fatty acids in humans," Prostaglandins, Leukotrienes and Essential Fatty Acids, vol. 80, no. 2-3, pp. 8591, 2009.

[30] M. K. Gregory, R. A. Gibson, R. J. Cook-Johnson, L. G. Cleland, and M. J. James, "Elongase reactions as control points in LongChain polyunsaturated fatty acid synthesis," PLoS ONE, vol. 6, no. 12, Article ID e29662, 2011.

[31] N. M. Jeffery, P. Sanderson, E. J. Sherrington, E. A. Newsholme, and P. C. Calder, "The ratio of n-6 to n-3 polyunsaturated fatty acids in the rat diet alters serum lipid levels and lymphocyte functions," Lipids, vol. 31, no. 7, pp. 737-745, 1996.

[32] S. S. Umesha and K. A. Naidu, "Vegetable oil blends with $\alpha$ linolenic acid rich Garden cress oil modulate lipid metabolism 
in experimental rats," Food Chemistry, vol. 135, no. 4, pp. 28452851, 2012.

[33] Y. S. Huang, M. S. Manku, and D. F. Horrobin, "The effects of dietary cholesterol on blood and liver polyunsaturated fatty acids and on plasma cholesterol in rats fed various types of fatty acid diet," Lipids, vol. 19, no. 9, pp. 664-672, 1984. 


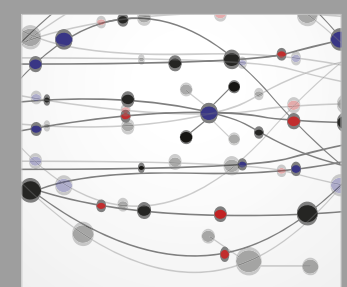

The Scientific World Journal
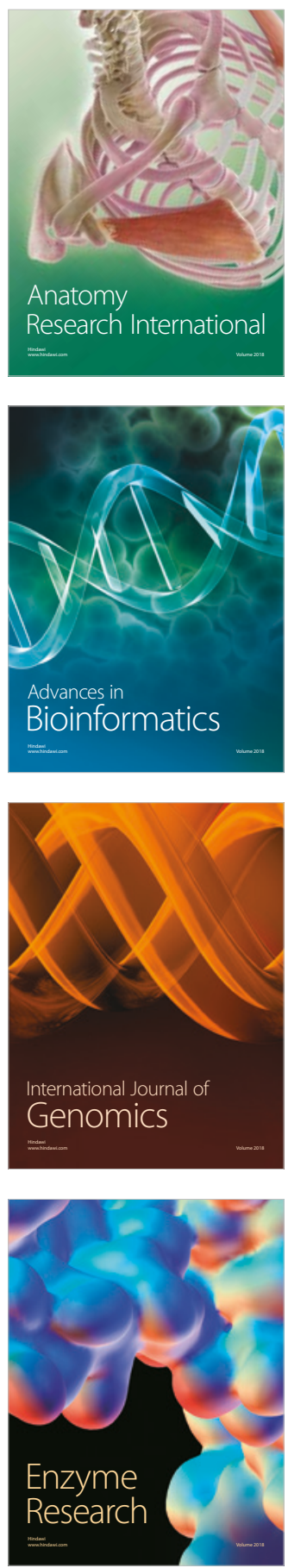
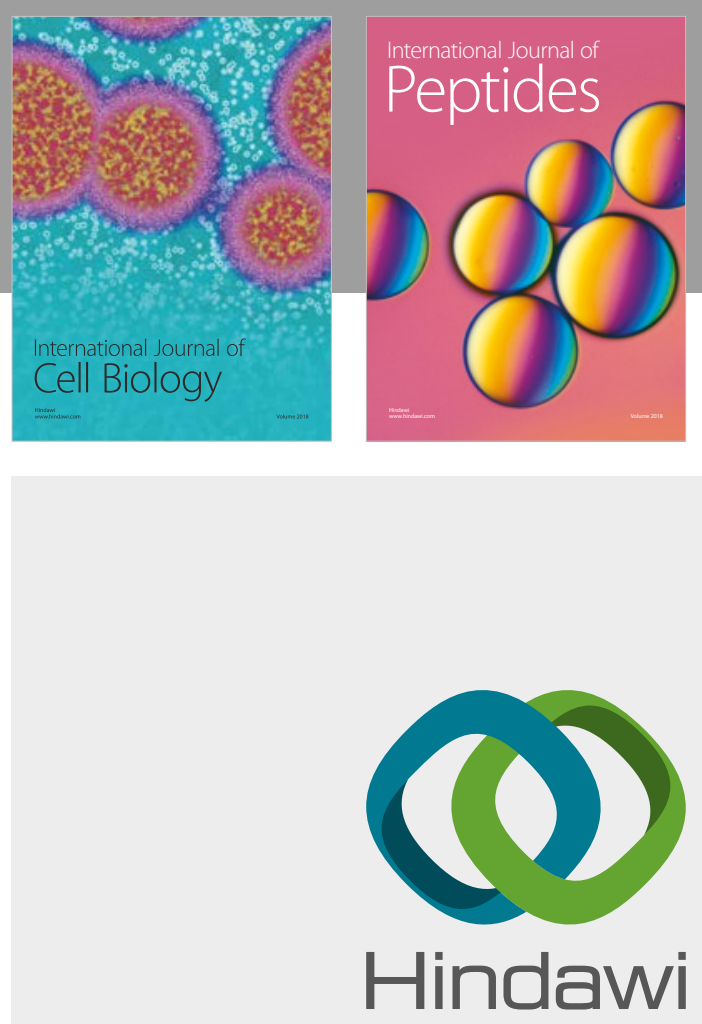

Submit your manuscripts at

www.hindawi.com
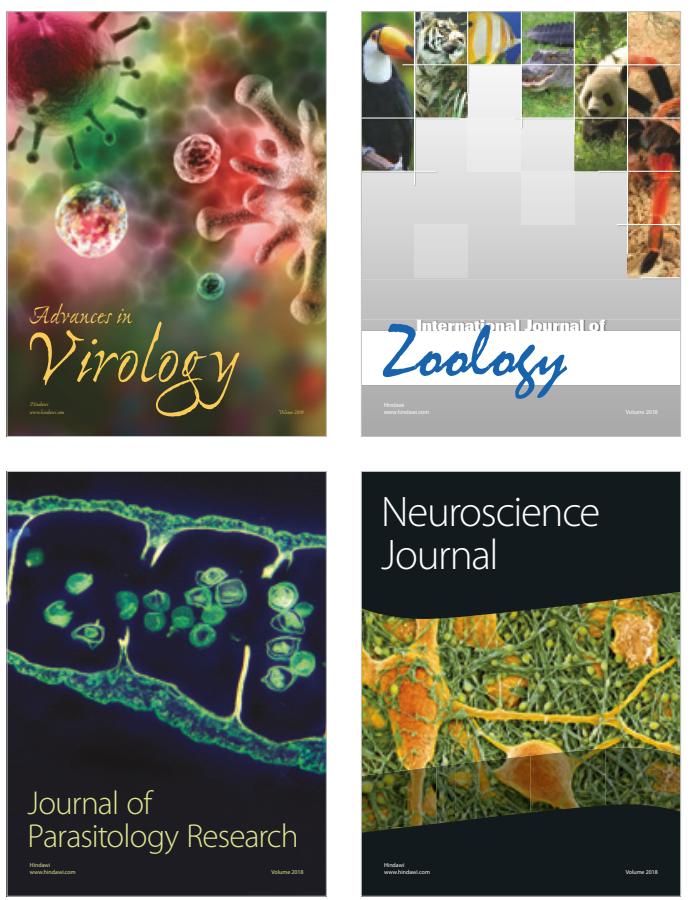
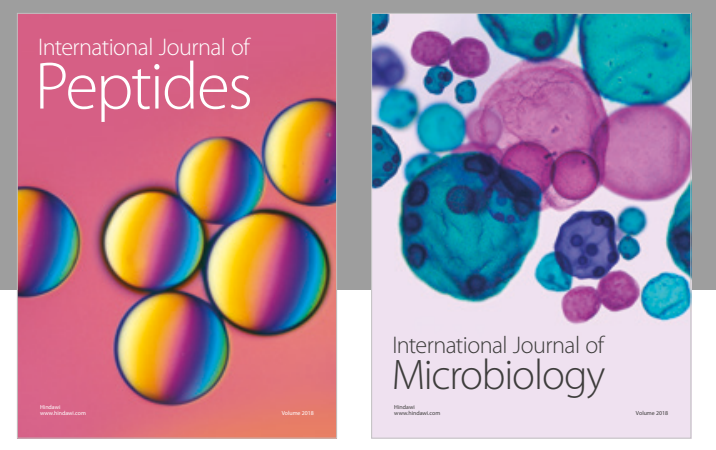

nternational Journal of Microbiology
Journal of
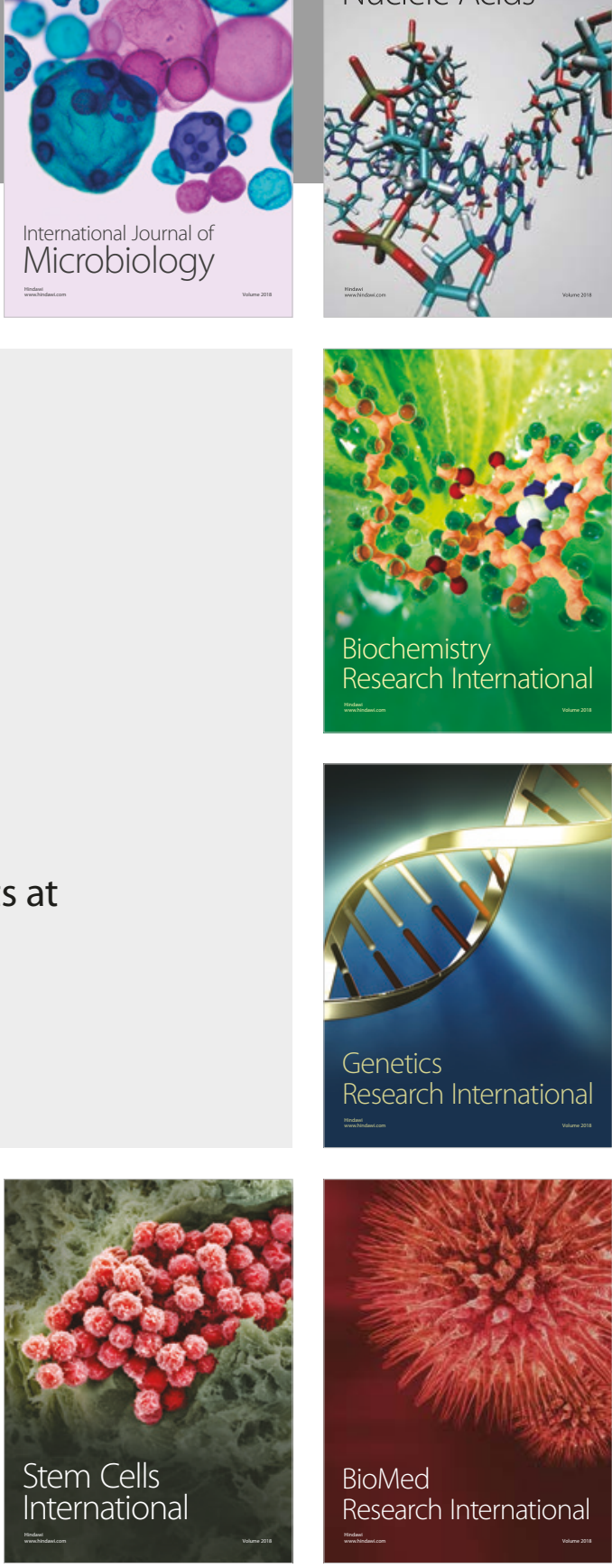
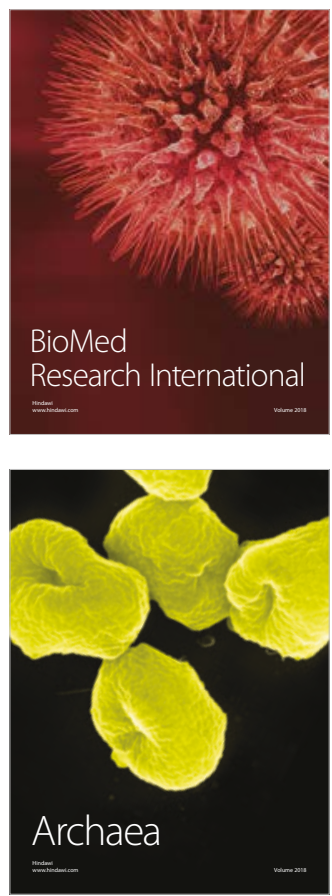